\title{
MUJERES Y EMBLEMAS: UNA VISIÓN SIMBÓLICA DE LA CONDICIÓN FEMENINA EN LA EDAD MODERNA
}

\author{
WOMEN AND EMBLEMS: A SYMBOLIC VISION OF THE FEMALE \\ CONDITION IN THE MODERN PERIOD
}

José Julio García Arranz

Universidad de Extremadura

\begin{abstract}
The difficult situation of women in the Modern Period, marked by the strong patriarchal and androcentric character of the official culture and ideology of the moment, and their high degree of social marginalization, has been frequently analysed through various literary sources such as theatre, fiction or travel literature, collections of proverbs and sermons, and, above all, moral and doctrinal texts. However, for some time now, a new approach to the issue has been attempted which has proven to be of singular importance when observing the effect of the aforementioned directives of the dominant ideology on the familial and social role of women: illustrated symbolic literature. Through its various forms of expression -emblems, badges, hieroglyphics, allegories- this genre became, especially from the final decades of the $16^{\text {th }}$ century, a perfectly calibrated and effective instrument when channelling the political, moral and doctrinal orientation of citizens. In the present study I offer an overview of how emblematic treatises and repertoires of allegories offer us excellent examples of the construction of the symbolic image that the dominant elites of modern times seek to spread and impose on the female gender, and their well-established and channelled behavioural norms.
\end{abstract}

KEYWORDS: Modern Period; Emblems; Female Marginality; Androcentric Control.

RESUMEN • La difícil situación de la mujer en la Edad Moderna, marcada por el fuerte carácter patriarcal y androcéntrico de la cultura e ideología oficiales del momento, y su alto grado de marginación social han sido analizados con frecuencia a través de diversas fuentes literarias como el teatro, la literatura de ficción o de viajes, las colecciones de refranes y sermones, y, sobre todo, los textos morales y doctrinales. Sin embargo, desde hace algún tiempo se está ensayando una nueva vía de aproximación al problema, y que resulta de singular importancia a la hora de constatar las mencionadas directrices de la ideología dominante sobre el papel familiar y social de la mujer: la literatura simbólica ilustrada. Por medio de sus diversas formas de expresión -emblemas, empresas o divisas, jeroglíficos, alegorías...-, este género se convirtió, sobre todo a partir de los decenios finales del s. XVI, en un instrumento perfectamente calibrado y eficaz a la hora de encauzar la orientación política, moral y doctrinal de los ciudadanos. En el presente trabajo ofrecemos una panorámica de cómo los tratados emblemáticos y los repertorios de alegorías nos ofrecen inmejorables ejemplos de la construcción de la imagen simbólica que las élites dominantes de los tiempos modernos pretenden difundir e imponer del género femenino, y de sus bien establecidas y canalizadas normas de comportamiento.

PALABRAS CLAVES: Edad Moderna; Emblemática; Marginalidad femenina; Control androcétrico. 


\section{LA MUJER EN LOS TIEMPOS MODERNOS: INTRODUCCIÓN}

El marcado carácter patriarcal y androcéntrico de la cultura e ideología oficiales de la Edad Moderna, que no mostraron reparos en sus intentos de someter a la voluntad del varón la vida y costumbres de la población femenina, y establecer estrictos límites para toda actividad desarrollada por la mujer más allá del restringido marco del hogar y de la crianza de los hijos, obtuvo su refrendo y legitimación institucional por distintos medios de expresión escrita, habitual vehículo de adoctrinamiento al servicio de los grupos dominantes. ${ }^{1}$ El teatro, la literatura de ficción o de viajes, las colecciones de refranes y sermones, y, sobre todo, los textos morales y doctrinales, tanto los de carácter normativo -en especial tratados sobre el matrimonio y manuales de confesores- como los de finalidad más edificante y didáctica -en forma de «instrucciones», "avisos» $\mathrm{o}$ "consejos»,$-^{2}$ ofrecen numerosos testimonios, ampliamente conocidos y analizados, que han inducido a los estudiosos a insistir en el alto grado de marginación social que padeció la mujer en los tiempos modernos. ${ }^{3}$

Considerada como "ser inferior» tanto por su propia condición natural ${ }^{4}$ como por el marco jurídico humano y divino en que se desenvuelve, la mujer debía hacer de la obediencia y la mansedumbre dos de sus principales obligaciones y virtudes, pues de ellas dependía el mantenimiento de la paz, la armonía y la felicidad familiares (Hernández Bermejo, 1990: 64-65). Con tales premisas, no es de extraña que el modelo oficial de relaciones entre marido y mujer se sustentara en el principio básico de la sumisión de la segunda al primero, y en la aceptación femenina de la autoridad de éste, ${ }^{5}$ castigándose con la pena de pecado mortal,

1. El presente trabajo se inscribe en el proyecto de investigación Biblioteca digital Siglo de Oro IV (código FFI2012-3436), dirigido por la profesora Nieves Pena Sueiro y financiado por el Ministerio de Economía y Competitividad del Gobierno de España, en el marco del VI Plan Nacional de I+D+i 2008-2011. De igual modo, su realización y presentación han contado con ayudas procedentes de la Junta de Extremadura y los Fondos FEDER a través del Grupo de Investigación "Patrimonio\&ARTE. Unidad de Conservación del Patrimonio Artístico», dirigido por la Dra. Pilar Mogollón Cano-Cortés. Constituye una versión actualizada de nuestro trabajo «Uxoriae virtutes. La imagen de la mujer virtuosa y su contexto en la cultura simbólica de la Edad Moderna», en J. L. de la Montaña Conchiña e I. Rodríguez Sánchez (coords.), De la intimidad y el susurro al poder, Badajoz, Servicio de Publicaciones de la Excma. Diputación Provincial de Badajoz, 2005, pp. 49-116, realizada expresamente para el presente número monográfico.

2. Sobre la imagen de la familia en este tipo de literatura moral y religiosa de la Edad Moderna vid. la obra de referencia fundamental de Mariló Vigil (1994); hemos consultado también la monografía de Hernández Bermejo (1990: 56 y ss.).

3. Algún autor -como Fernández Álvarez, 1989: I, 173 y ss.-, ha afirmado que la discriminación de la fémina como eterno menor de edad -o "vaso frágil», conforme a un eufemismo muy al uso en la época-, y, por tanto, como criatura poco digna de la confianza masculina, constituyó uno de los rasgos más definitorios de la sociedad del Antiguo Régimen; fue un tiempo de "reclusión y silencio" para el género femenino, según podemos leer en un epígrafe del libro de Eulalia de Vega (1996: 28). Sin embargo, es difícil saber hasta qué punto estos principios propugnados por la ideología dominante eran aplicados de forma generalizada en la realidad. Como señala Mariló Vigil (1994: 27): "A medida que el tiempo avanzaba, sobre todo en el s. XVII, las mujeres fueron siendo, además de parleras, ventaneras, callejeras, visitadoras, amigas de fiestas y enemigas de sus rincones, de sus casas olvidadas», en una pugna tenaz por el derecho a la libertad de movimientos.

4. Tanto la Anatomía como la Fisiología renacentistas confirmaron la innata inferioridad de la mujer y su limitada función reproductora. Sus cuerpos y mentes son tan débiles -según testimonio de la época-, que debían permanecer dentro de los confines protectores del hogar para poder mantenerse a salvo (Anderson y Zinsser, 1991: II, $120)$.

5. En efecto, el primer nivel de relación que se establecía entre marido y mujer se basaba en la afirmación del principio de autoridad de aquél, y en la articulación de los medios necesarios para ejercitarlo sin trabas: los tratadistas morales elaboraron por ello un discurso dirigido a la mujer en el que la culpabilización y la represión eran componentes esenciales (Hernández Bermejo, 1990: 66). 
e incluso el aborrecimiento general de la comunidad, cualquier intento de desafío al orden establecido. ${ }^{6}$ Esta tesis fue respaldada por el recurso a la auctoritas de una ya prolongada tradición literaria con una doble vertiente: la emanada de la propia doctrina de la Iglesia, ${ }^{7}$ y la procedente de la poco disimulada misoginia de los autores clásicos -en especial Platón, Aristóteles o Plutarco-, que recurrieron con frecuencia en sus argumentos a la supuesta debilidad congénita del sexo contrario. ${ }^{8}$ Viene aquí muy a propósito un pasaje de Juan de Horozco y Covarrubias, arcediano de Cuéllar, incluido en sus Emblemas morales:

«Y en lo que toca al interceder las mugeres con sus maridos con más instancia de la que convendría, no se escusa referir la ley de Platón que puso en su República, y es que el govierno de la casa y de las cosas della estén a cargo de la muger; y todo lo que es de las puertas a fuera sea negocio del varón: y conforme a esto la muger no tratará del oficio de su marido» (Horozco, 1603/1604: III, emb. 36, 173v).

Además de las culturales, existieron al mismo tiempo otras razones político-sociales que redundaron en la incondicional dependencia femenina del cabeza de familia. La sociedad moderna era entendida como un todo jerarquizado en diversos estados a los que correspondían sus respectivos papeles, siendo la familia una reproducción a escala reducida de esta organización estamental. Tal estructuración se basa, en primera instancia, en el criterio de autoridad que preside el sistema de relaciones sociales y políticas; en segundo lugar, responde a la diferenciación que en el seno de la unidad familiar supone la pertenencia a uno u otro sexo: el padre y los hijos varones, a su vez jerarquizados entre sí y consagrados por norma al desempeño de una función pública que garantice el sustento de los suyos, se sitúan en un nivel superior al de la madre y las hijas, instruidas y adoctrinadas, por el contrario, para vivir en el marco reducido del ámbito doméstico (Vigil, 1994: 11 y ss.; Hernández Bermejo, 1990: 100-101).

Tampoco desde la intelectualidad del momento se ofrecieron alternativas a los anteriores posicionamientos. Pese a la revolucionaria idea central del humanismo cristiano renacentista -defensa de la autonomía del individuo frente al orden ritual establecido para relacionarse con la divinidad, de la que se deduce la igualdad esencial de hombres y mujeres-, tanto Erasmo de Rotterdam como sus epígonos españoles, entre los que se encuentran mentes tan

6. Los textos morales admiten, incluso, el castigo de la mujer insumisa o rebelde por parte del patriarca de la casa -padre o marido- siempre y cuando existiera "causa justa" para tal medida. Sin embargo, a pesar de la presión social, las mujeres pudieron desarrollar fórmulas específicas de resistencia desde las distintas posiciones a las que fueron destinadas en los tiempos modernos (Nielfa Cristóbal, 1991: II, 605).

7. Ésta se encuentra definida ya en el Génesis -recordemos que, según el relato bíblico, la hembra fue creada del costado del varón-, y completada posteriormente en los escritos de Pablo de Tarso y Agustín de Hipona, que justificaban la sumisión femenina con el tan manido tópico bíblico del pecado original, que permite achacar a la inconsciencia y ligereza de la mujer la perdición del linaje humano sin mayores complicaciones intelectuales. Pablo, por ejemplo, afirma en una de sus Epístolas: "Sed sumisos los unos a los otros en el temor de Cristo. Las mujeres a sus maridos, como al Señor, porque el marido es cabeza de la mujer, como Cristo es Cabeza de la Iglesia, el salvador del Cuerpo. Así como la Iglesia está sumisa a Cristo, así también las mujeres deben estarlo a sus maridos en todo" (Ef 5, 21-24); Cfr. también 1 Co 7, 39, o Col 3, 18. Esta cita, y los restantes pasajes bíblicos reproducidos en este trabajo, proceden de la Biblia de Jerusalén (1994).

8. Vid. sobre estas cuestiones Hernández Bermejo, 1990: 64. En los autores grecolatinos citados no faltan alusiones a la potencial irracionalidad de la mujer -debida, en su opinión, a la insaciabilidad del útero, principal causante de la histeria y otros trastornos mentales femeninos-, y su propensión a la enfermedad y la locura sin la oportuna intervención del varón. Incluso se llega a restar protagonismo a la mujer en el proceso de la procreación, pues ella -según Aristóteles- aporta únicamente la "materia», en tanto la vida y la esencia del embrión proceden tan sólo del esperma. 
preclaras como las de Luis Vives, Antonio de Guevara, Pedro de Luján, Fray Luis de León o Miguel de Cervantes, defendieron ardientemente la sumisión de las mujeres a los lazos del modelo de familia patriarcal de la tradición greco-latina-judeo-cristiana (Vigil, 1994: 18 y ss). Todos ellos -incluido el propio Erasmo con sus Diálogos- compusieron tratados de aliento pedagógico en los que se aconsejaba proporcionar a las féminas una educación intelectualmente sofisticada y fuertemente ideologizada con la que, a su entender, se adaptarían con más facilidad a sus papeles de dóciles hijas, complacientes esposas y eficientes madres. En estos escritos -que, en la práctica, restringían las potencialidades sociales de las mujeres a cuatro posiciones honrosas: doncella, casada, viuda o monja-se propugna encarecidamente el recato de éstas, tanto en la conveniencia de que guarden permanente silencio, como en la precaución de que desarrollen la menor actividad pública posible, manteniéndose alejadas de la calle y de otras amistades femeninas y, por descontado, masculinas (Nielfa Cristóbal, 1991: II, 602; Escalera Pérez, 2000: 783); ${ }^{9}$ todas estas consignas tendrán su estricto correlato, como veremos, en los libros de emblemas coetáneos, obra también de instruidos humanistas durante los primeros decenios del género.

Dentro de estas coordenadas, el filólogo y pedagogo valenciano Juan Luis Vives, autor de un tratado con el título Libro llamado instrucción de la mujer cristiana (Valencia, 1528), insistió en que la fémina, criatura caracterizada por sus «vanos parloteos», «tornadizos pensamientos" y «lubricada ligereza», había de permanecer continuamente ligada a los quehaceres de la casa, y, por tanto, en perfecta sintonía con las sentencias de Pablo de Tarso, ${ }^{10}$ redundó en la conveniencia de apartarla de actividades extrahogareñas como, por ejemplo, la enseñanza:

"Así que, puesto que la mujer es un ser flaco y no es seguro su juicio, y muy expuesto al engaño (según mostró Eva, madre de los hombres, que por muy poco se dejó embobecer del demonio), no conviene que ella enseñe, no sea que una vez que se hubiese a sí misma persuadido de una opinión falsa, con su autoridad de maestra influya en sus oyentes y arrastre fácilmente a los otros a su propio error». ${ }^{11}$

Testimonios como éste ilustran la culminación del proceso de paulatina exclusión de aquellas parcelas de trabajo institucional que el género femenino había conquistado durante los siglos medievales. Con la excusa convencional de la «defensa de la castidad»,

9. Como ha señalado Mariló Vigil (1994: 5), esta actitud responde a la paradójica coexistencia de la corriente igualitaria del humanismo cristiano con un orden social rígidamente jerarquizado, teocrático y cerrado. La misma autora (1994: 16, 24 y ss) añade que este "furor panfletario antifemenino" que desde fines del siglo XV se desata entre moralistas y humanistas, pudo responder a una inadaptación de las mujeres a las pautas de comportamiento previstas para ellas por la ideología masculina emergente, y a los consiguientes conatos de rebeldía.

10. Pablo dejó algunas citas muy explícitas y rotundas en lo referente al obligado recato y compostura de la mujer. Así, aconseja que se desconfíe de las viudas jóvenes, "[...] porque cuando les asaltan los placeres contrarios a Cristo, quieren casarse e incurren así en condenación por haber faltado a su compromiso anterior. Y además, estando ociosas, aprenden a ir de casa en casa; y no sólo están ociosas, sino que se vuelven también charlatanas y entrometidas, hablando de lo que no deben" (1 Tm 5, 11-13); en la misma epístola leemos: "La mujer oiga la instrucción en silencio, con toda sumisión. No permito que la mujer enseñe ni que domine al hombre. Que se mantenga en silencio. Porque Adán fue formado primero y Eva en segundo lugar» (1 Tm 2, 11-13).

11. Trad. de L. Riber en Vives, 1947: I, 991. El texto procede de Fernández Álvarez (1989: I, 173). Este mismo autor (1989: I, 174-175), analizando las escasas posibilidades que tenía la mujer en el mundo laboral de la España moderna, indica que, entre más de un centenar de profesiones posibles, la mujer tan sólo tenía acceso a algunas de las más discretas o humildes -confitera, pastelera, panadera...-, ejerciendo en exclusiva las de lavandera, hilandera y comadrona o partera, labores que, en cualquier caso, son subsidiarias e imposibilitan su independencia económica. Se trata, además, de oficios «domiciliarios» que podían realizarse fuera del control social, y ser fácilmente compaginables con las tareas domésticas (De Vega, 1996: 31 y ss.). 
se expulsa a los componentes femeninos de las corporaciones gremiales al tiempo que se declara su actividad "deshonesta e infamante», no sólo para la mujer que la realiza, sino también para los hombres que permitían que aquélla la asumiese (De Vega, 1996: 30-32). Tan solo en el ámbito urbano encontramos mujeres trabajando en industrias o despachos familiares -en una peculiar simbiosis de hogar y taller-, o incluso, en el Madrid del s. XVII, se documenta presencia femenina en los gremios de curtidores, pasamanería o manufactura de tapices (Nielfa Cristóbal, 1991: II, 604). Pero se trata de raras excepciones: sobre madres e hijas de las familias poco pudientes acabaron recayendo con exclusividad las responsabilidades domésticas, consistentes básicamente, como indicamos más arriba, en la crianza y educación de los hijos -pues su capacidad reproductora continuó marcando su identidad y sus vidas durante todo el Antiguo Régimen-, y en «[...] levantarse por la mañana, andar revuelta [...] riñiendo a las mozas, despertando a los mozos y vistiendo a sus hijos [...] hacer su colada, lavar su ropa, ahechar su trigo, cerner su harina, amasar su masa, cocer su pan, barrer su casa, encender su lumbre, poner su olla, y después de haber comido tomar su almohadilla para labrar o su rueca para hilar», según pormenoriza Antonio de Guevara, predicador y obispo de Mondoñedo, en sus Epístolas familiares (según Vigil, 1994: 109).

En la España de estas centurias la situación se agrava a causa de dos factores añadidos: el carácter tremendamente conservador de su sociedad, y la tiranía del concepto de «la honra», que se sustenta esencialmente en la honestidad de las mujeres de la familia, esto es, en las incuestionables fidelidad de la esposa y virginidad de las hijas. La protección a ultranza de esa honra, responsabilidad del hombre fuerte de la unidad familiar -padre, marido o hermano mayor- ${ }^{12}$ tenía, con demasiada frecuencia, consecuencias negativas para el género femenino: en primer lugar, la insatisfacción que producían los partos de niñas por las complicaciones que llevaban aparejados; en segundo, el hecho que los padres desearan desentenderse cuanto antes de esta incómoda responsabilidad, casando a sus hijas o, cuando éstas no podían ser dotadas para el matrimonio, obligándolas a ingresar en conventos, por lo general en contra de su voluntad (Fernández Álvarez, 1989: I, 193).

Así pues, las mujeres del momento, en especial las de humilde condición, se encontraban abocadas a la vida doméstica, antes o después de acceder al matrimonio -considerado, de acuerdo con la opinión generalizada hasta fechas dolorosamente recientes, el estado perfecto para una mujer honrada, la razón principal de su existencia-,$^{13}$ o a la vida religiosa, siempre y cuando no se recurriera a otras alternativas más "problemáticas" para la delicada honra familiar, como el servicio de criadas o la mancebía, situaciones habitualmente superpuestas. En cuanto a las jóvenes que contraían el vínculo matrimonial, las más de las veces concertado por los progenitores, ${ }^{14}$ las verdaderas dificultades se hacen palpables con el ini-

12. La importancia que este concepto alcanzó en la mentalidad del español del Siglo de Oro llevó al gobierno de los Austrias a dictar leyes y tomar medidas contra la infidelidad conyugal y la pérdida del honor en el matrimonio; estas normas concedían al marido ultrajado la facultad de matar a la mujer infiel y a su cómplice sorprendido in fraganti, tanto por su propia mano como mediante asesinos pagados, quedando así el esposo -o el padre, o el hermano de la adúltera- en completa impunidad (Deleito y Piñuela, 1994: 74-75).

13. Pablo de Tarso indicó al respecto: «Quiero, pues, que las jóvenes se casen, que tengan hijos y que gobiernen la propia casa y no den al adversario ningún motivo de hablar mal; pues ya algunas se han extraviado yendo en pos de Satanás» (1 Tm 5, 14-15), añadiendo en otro lugar (1 Cor 7, 9): "Pero si no pueden contenerse, que se casen: mejor es casarse que abrasarse».

14. En efecto, pese a que la Iglesia defendía oficialmente la libre voluntad de los contrayentes, la legislación civil prohibía el matrimonio de los menores de edad sin autorización paterna, circunstancia que favoreció la intervención de los progenitores (Testón Núñez, 1985: 26, 51 y ss.). Luis Vives, en su tratado citado, defiende que sean los padres los que busquen esposo para sus hijas, pues su mayor experiencia y su permanente preocupación por el destino de sus vástagos les capacita, en su opinión, para hacer la elección correcta (Rodríguez Sánchez, 1996: 13).

IMAGO, NÚM. 10, 2018, 7-52 
cio de la convivencia marital: recordemos aquí el frecuente tópico literario de la malcasada; no faltan tampoco testimonios de ello en la literatura didáctico-moral del periodo.

En La perfecta casada, librito de carácter formativo compuesto por fray Luis de León, obligada referencia durante los tiempos del Barroco para toda mujer que se enfrentara a los rigores de la vida conyugal, se nos pone sobre la pista de esta problemática. En el segundo capítulo de la obra, después de otorgar a la hembra calificativos como «quebradiza» y «melindrosa» en sus costumbres e ingenio, o "flaca y deleznable más que ningún otro animal» en su naturaleza, la condena a una resignación sumisa e inapelable frente al capricho del marido «recio» e «indigesto», al que se encuentra indefectiblemente ligada, para lo bueno. y para lo malo, por el sagrado vínculo del matrimonio:

"Que por más áspero y de más fiera condición que el marido sea, es necesario que la mujer lo soporte [...] ¡Oh que es un verdugo! Pero es tu marido ¡Es un beodo! Pero el nudo matrimonial le hizo contigo uno ¡Un áspero, un desapacible! Pero, miembro tuyo ya, y miembro el más principal» (Luis de León, 1950: 109). ${ }^{15}$

Además de la sumisión y la ignorancia, ${ }^{16}$ la mujer moderna debía también hacer gala de las siguientes «virtudes» maritales, según especifica a mediados del quinientos Pedro de Luján en sus Coloquios matrimoniales:

«La mujer casada ha de ser que tenga gravedad para salir fuera de casa, cordura para gobernarla, paciencia para sufrir al marido, amor para criar a sus hijos, afabilidad para con sus vecinos, diligencia para guardar su hacienda, muy cumplida en cosas de honra, enemiga de livianas y aun de liviandades de moza, y amiga de honesta compañía». ${ }^{17}$

No faltan en las relaciones de viajeros contemporáneas jugosos testimonios relativos a la discriminatoria situación que sufre la mujer casada hispana -y, por extensión, la de toda la Europa católica- en los ss. XVI y XVII. Un ilustrativo caso, tal vez algo sensacionalista, es el del aristócrata francés Antoine de Brunel en la conocida descripción que hace de las costumbres más llamativas de nuestra sociedad en el Siglo de Oro:

«Por lo demás, los maridos que quieren que sus mujeres vivan honestamente se hacen primeramente tan absolutos, que las tratan casi como a esclavas, por miedo a que una honesta libertad las haga emancipar más allá de las leyes del pudor, que son muy poco conocidas y mal observadas en este sexo. Me han asegurado que en Andalucía los maridos las tratan como a niños o como a criadas. Porque cuando toman su comida, las hacen aproximarse a la mesa no para comer con ellos, sino para servirlos; y si no les dan ese permiso y desean mantenerlas en un grado de sujección más honesta, les dan de comer desde su mesa al suelo, donde ellas están sentadas sobre alfombras o sobre cuadrantes, a la moda de los turcos» (De Brunei, 1665; en García Mercadal, 1959: 141).

15. El texto procede de Fernández Álvarez, 1989: I, 176.

16. Como indica Á. Rodríguez Sánchez (1996: 17), diversos tratadistas morales de los ss. XVII y XVIII, como Gaspar de Astete en su Tratado del gobierno de la familia y estado de las viudas y doncellas (Burgos, 1603), o fray Antonio Arbiol, en La familia regulada con doctrina de la Sagrada Escritura y Santos Padres de la Iglesia Católica (Zaragoza, 1715), insisten en que Dios no quiere que las mujeres sean «bachilleras» o "tenidas por doctas» conforme al argumento de que resulta «muy peligroso enseñar a leer y escribir a las hijas», pues el acceso a la lectura puede complicar su escaso entendimiento. Pese a que algunos humanistas incidieron en las bondades de la educación femenina, la realidad es que el nivel cultural de las mujeres de nuestro Siglo de Oro fue muy escaso.

17. La cita procede de Rodríguez Sánchez (1996: 15). 
No obstante, hay que indicar que otros viajeros foráneos se sorprenden precisamente de lo contrario: la aparente abundancia de mujeres en nuestro país «que al parecer se han adueñado por completo de calles y plazas y además son impúdicas, disolutas y corruptas» (Vigil, 1994: 29).

El grado de sometimiento femenino que apuntan algunos de estos testimonios explica, por ejemplo, la breve anotación de Teresa de Jesús en sus Fundaciones, en la que subraya las ventajas de profesar en un convento para evitar así la tiranía de un marido no deseado (Fernández Álvarez, 1989: I, 176).

\section{LUJURIA Y PROSTITUCIÓN: LA IMAGEN SESGADA DE LO FEMENINO EN LA LITERATURA SIMBÓLICA ILUSTRADA MODERNA}

Junto a los referidos testimonios escritos, que nos permiten entrever fugazmente, al menos sobre el papel, una existencia cotidiana llena de restricciones y prejuicios, existe otra vía de aproximación al problema a la que se ha ido prestado de manera progresiva una creciente atención, ${ }^{18}$ y que resulta de singular importancia a la hora de constatar las mencionadas directrices de la ideología dominante sobre el papel familiar y social de la mujer: la literatura simbólica ilustrada. Por medio de sus diversas formas de expresión -emblemas, empresas o divisas, jeroglíficos, alegorías...-, este género se convirtió, sobre todo a partir de los decenios finales del s. XVI, en un instrumento perfectamente calibrado y eficaz, dado su alto grado de implantación en la sociedad del momento, a la hora de encauzar la orientación política, moral y doctrinal de los ciudadanos.

Dos de estas manifestaciones -los emblemas y las alegorías-, gracias a su especial dimensión formativa y ético-moral, desempeñaron un papel preponderante en el marco de tales propósitos. Los tratados emblemáticos y los repertorios de figuras alegóricas nos ofrecen inmejorables ejemplos de la construcción de la imagen simbólica que las élites dominantes de los- tiempos modernos -en especial las del ámbito eclesiástico- pretenden difundir e imponer del género femenino, y de sus bien establecidas y canalizadas normas de comportamiento. De ello proporcionaremos abundantes ejemplos en las siguientes páginas.

En la sociedad moderna se generalizó un doble -y muy contrastado- discurso sobre la mujer como concepto teórico: por una parte, se la equipara a una criatura peligrosa, objeto de tentación y de pecado carnal, inevitablemente vinculada al nefasto comportamiento de la Eva bíblica; por otra, se la rodea de un aura de exaltación e idealización -herencia de la tradición medieval del amor cortés- que permite su asociación, en último extremo, a la imagen de la

\footnotetext{
18. Tras los pioneros y documentados trabajos de R Escalera Pérez (2000 y 2001), que constituyen una muy completa panorámica de los distintos enfoques de la condición femenina en los libros de emblemas españoles y europeos del momento, los textos sobre este tema proliferaron durante la siguiente década, procedentes esencialmente de la vertiente de los estudios clásicos. Cabe destacar las numerosas aportaciones de M $^{\mathrm{a}}$ del Mar Agudo Romeo (2004, 2008a, 2008b, 2009 y 2011), así como las de B. Antón (2008 y 2009) y G. Senés (2006). A ellas deben sumarse otros trabajos desde otros enfoques metodológicos distintos, como nuestra panorámica (García Arranz, 2005), los artículos de E. Martínez Cabezón (2011) y Julia D'Onofrio (2016), o las contribuciones de V. Mínguez Cornelles (2010), I. Rodríguez Moya (2011), o de ambos en colaboración (2013), estas últimas sobre la iconografía del matrimonio y la ceremonia nupcial en el ámbito preferentemente cortesano, temática a la que podemos sumar el relevante trabajo de D. Russell (2005).
} 
Virgen María, siendo sus principales valores la humildad, la pureza y la discreción. La Emblemática moderna, como vamos a ver, fue un fiel reflejo de ambos modelos femeninos, si bien, cuantitativamente, predominan los ejemplos que nos advierten de la vertiente más negativa y oscura de esta concepción bipolar (Agudo Romeo, 2004: 109). La sexualidad femenina se plantea como una amenaza a causa de su supuesta naturaleza insaciable y lujuriosa, causante de un permanente estado de insatisfacción capaz de transformar a las damas más honorables en vulgares busconas o adúlteras, que atrapan y arrebatan la hombría al varón confiado, tal y como se cuenta de la filistea Dalila en el Antiguo Testamento (Anderson y Zinsser, 1991: II, 115).

Ello resulta perfectamente comprensible si tenemos en cuenta que los libros de emblemas y las colecciones de alegorías se convirtieron, conforme se fue imponiendo la concepción barroca del mundo, en un medio cada vez más recurrente en manos de teólogos y moralistas destinado, como ha indicado la profesora Escalera Pérez (2000: 769), a reprender, aconsejar u ofrecer modelos de comportamiento a las féminas que permitieran regular adecuadamente sus costumbres, al tiempo que sirve de aviso a los hombres del peligro potencial que aquéllas presuponen. Como ya indicó Beatriz Antón (2008: 826, nota 4), el género emblemático recurrió con asiduidad a la figura de la mujer en sus diversos roles sociales de puella, uxor y meretrix. En efecto, basta echar un rápido vistazo a la literatura simbólica de los ss. XVI y XVII para comprobar de forma inmediata las connotaciones negativas con que se inviste a la mujer -en especial aquélla que no se somete o se resiste a las normas de conveniencia establecidas-, representada como temible objeto de fatal atracción que puede conducir a la destrucción física y moral de aquellos varones imprudentes y necios que se rinden a sus encantos. Éstos son -si nos atenemos a una imagen emblemática propuesta por Gabrielle Simeoni (1574: 186-187)-como polillas o mariposas que acuden a una llama destructora, metáfora de los hombres inconscientes que, al dejarse enredar en requiebros de amores, acaban perdiendo de forma deshonrosa tanto su cuerpo como su alma.

Una impactante muestra de esta caracterización es la que nos ofrece Sebastián de Covarrubias, canónigo de Cuenca y consultor del Santo Oficio, en sus Emblemas morales, composición que nos puede servir para entrar en materia. El eclesiástico recurre a la figura de una mujer desnuda de pie, dispuesta sobre una concha que flota en medio del mar -probable versión icónica de la diosa Venus-, sosteniendo en la mano derecha un recipiente con llamas en su interior al tiempo que sujeta una tela que ondea al viento [fig. 1], modelo alegórico procedente de un cuadro cuya autoría no se nos precisa. El epigrama con que Covarrubias aclara el sentido de esta personificación es el siguiente:

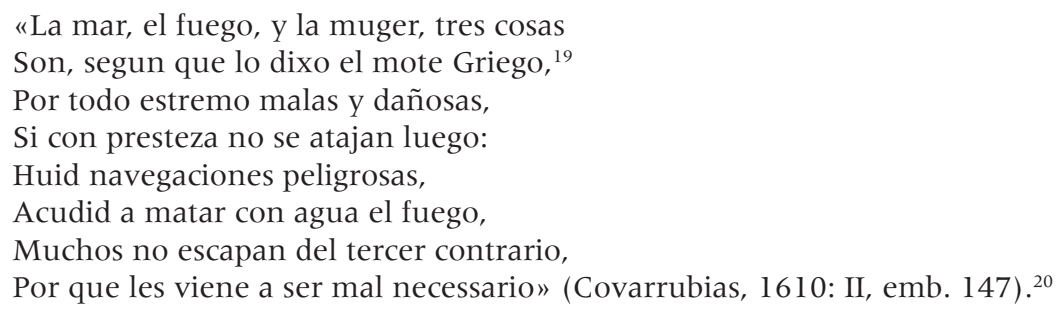

19. El lema griego del emblema puede traducirse como «Tres cosas malas». Vid. sobre este emblema Escalera Pérez, 2000: 776-777.

20. Fol. 147r. Tal vez no tenía la conciencia muy tranquila el canónigo conquense cuando compuso este emblema, pues así se excusa al final de su declaración: "[...] yo no soy amigo de ultrajar las mugeres, no embargante que este proverbio, ni otros tales no se deven entender de las que son buenas y dignas de ser celebradas con eterna memoria". 


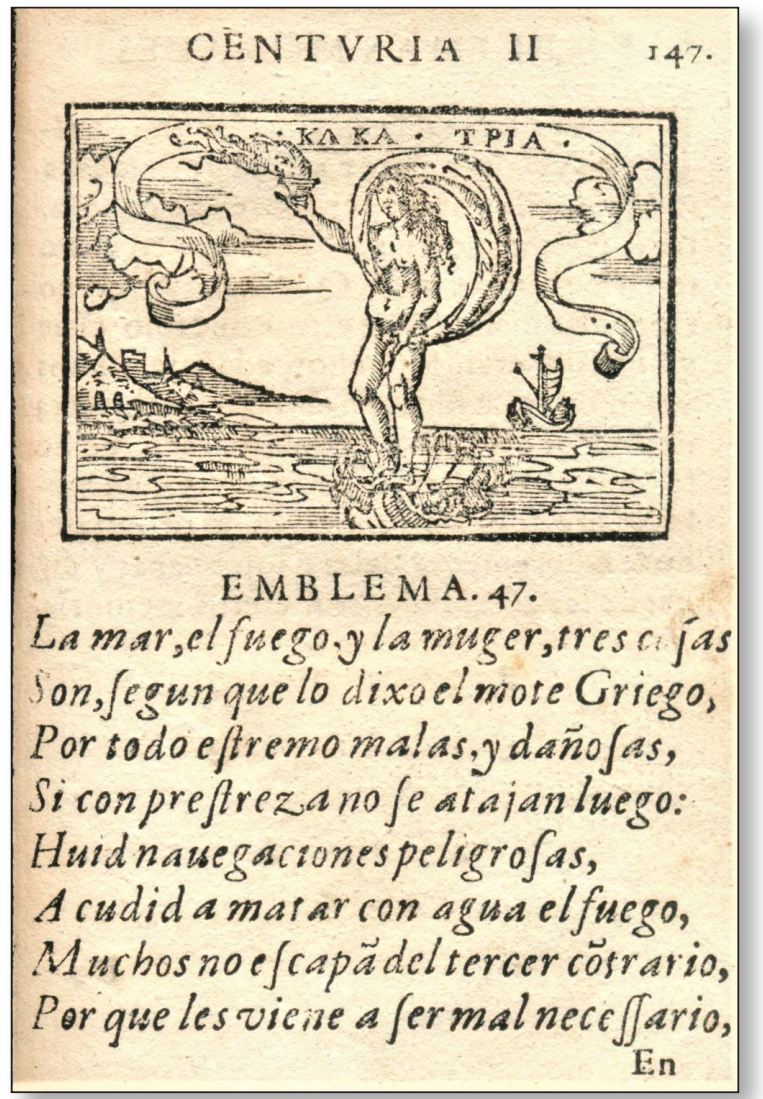

Fig. 1. Sebastián de Covarrubias, Emblemas morales, Madrid, 1610. Cent. II, emb. 47.
Frente al terrible peligro que suponen las mujeres librepensadoras, incluso más destructor que las llamas de un incendio o las olas del mar a causa de las escasas «vías de escape» que permiten al género varonil -ya Mateo Alemán o Quevedo sugirieron en sus escritos que las féminas son insoportables, pero al mismo tiempo imprescindibles- (Vigil, 1994: 118), el emblemista nos aconseja que "vivamos recatados» y alejados de su trato como seguro remedio para evitar su influencia y perjuicios.

Como acabamos de comprobar en el ejemplo de Covarrubias, los emblemistas, incluido el propio Andrea Alciato en su Emblematum liber, recurrieron a diversas imágenes míticas -pues la mitología fue el ámbito más socorrido cuando se pretendía moralizar sobre ciertas cuestiones escabrosas sin levantar las iras de los censores eclesiásticospara proponer iconos simbólicos en los que determinados elementos de seducción adquieren de manera sistemática rasgos ostentosamente femeninos.

Voluptuosa forma de mujer posee, por ejemplo, la representación de la fabulosa Escila. Se trata de un monstruo marino que habitaba emboscado en el

estrecho de Mesina, situado entre Sicilia y la península italiana, y que personifica a los funestos arrecifes que, como cantaron los poetas clásicos, ${ }^{21}$ arrastraban y destruían a las embarcaciones que se aventuraban por aquel paso. Según la tradición literaria, poseía una naturaleza biforme, mujer desde la cabeza hasta el pubis y con la parte inferior transformada en feroces perros que, al igual que hace la mujer lúbrica, devoran cuanto se pone a su alcance [fig. 2]; el mito se convierte así, de acuerdo con uno de los emblemas de Alciato, en abierta alegoría de la Desvergüenza -Impudentia- (Sebastián López, 1985: 103-104). ${ }^{22}$ Del mismo modo, la planta del loto que se cría al sur de la isla de Chipre, en la fabulosa región de los lotófagos, ${ }^{23}$ y cuyo fruto produce un efecto que hace perder a los viajeros su afán de regresar al suelo paterno y los retiene, por tanto, en aquellos territorios, adquiere en la ima-

21. Fueron varios los compañeros de Ulises que fueron devorados por el monstruo cuando su nave llegó a las proximidades de la gruta que le servía de guarida, según el relato de la Odisea XII, 73 y ss.

22. Emblema 68 (ed. 1608): Impudentia. Escribe Diego López, célebre comentarista hispano de los emblemas de Alciato, al respecto de esta personificación (1615: 193r) que es símbolo de la lujuria "[...] porque qualquiera libidinosa es necessario, y forçoso, que junte sus partes baxas con perros, y lobos, significando que jamás harta su secreta hambre, y luxuria, tragando torpezas, y haziendas agenas», y de la desvergüenza (1615: fol. 193 v), "Porque ninguna ramera ay que tenga verguença, porque esta virtud no se halla en alguna de ellas».

23. Vid. sobre este episodio Od. IX, 82 a 104.

IMAGO, NÚM. 10, 2018, 7-52 
gen de otro emblema del jurista milanés una morfología femenina [fig. 3]. Se compara así el olvido de la patria que proporciona el dulce fruto con la seducción de la mujer, capaz de insensibilizar a los hombres y hacerles renunciar a sus parientes y amigos (Sebastián López, 1985: 152-153); ;4 añade por ello Diego López (1615: 283r) que el símbolo puede aplicarse, de igual modo, a los jóvenes que "gustando de los deleytes, y vicios dificultosamente buelven a los estudios que començaron».

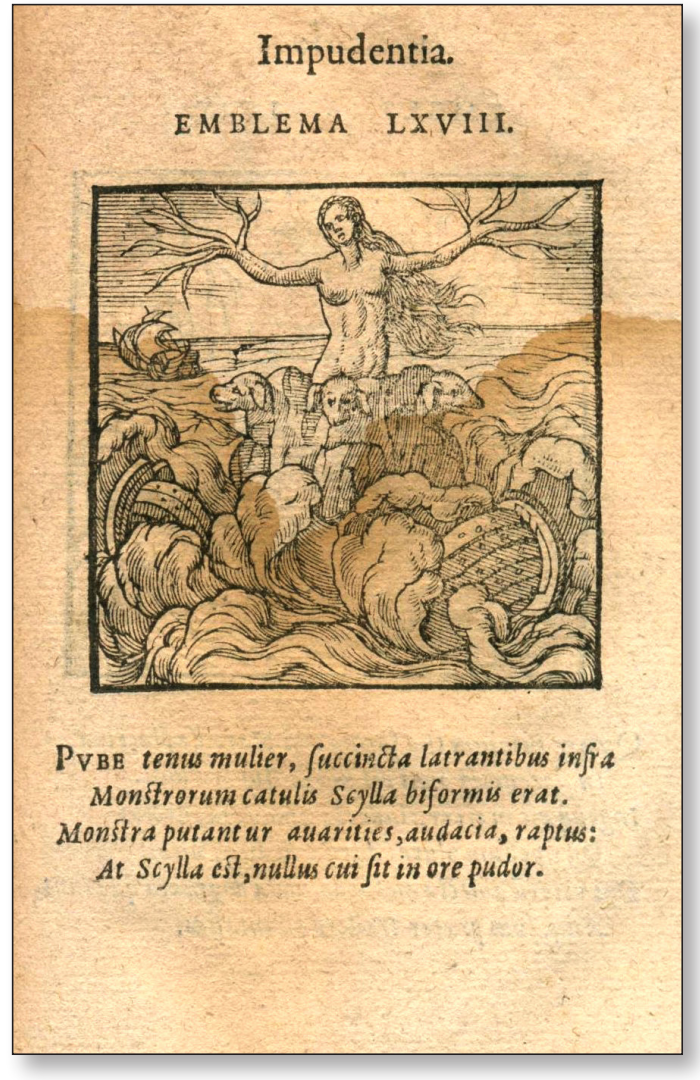

Fig. 2. Andrea Alciato, Emblemata, Amberes, 1608. Emb. 68 .

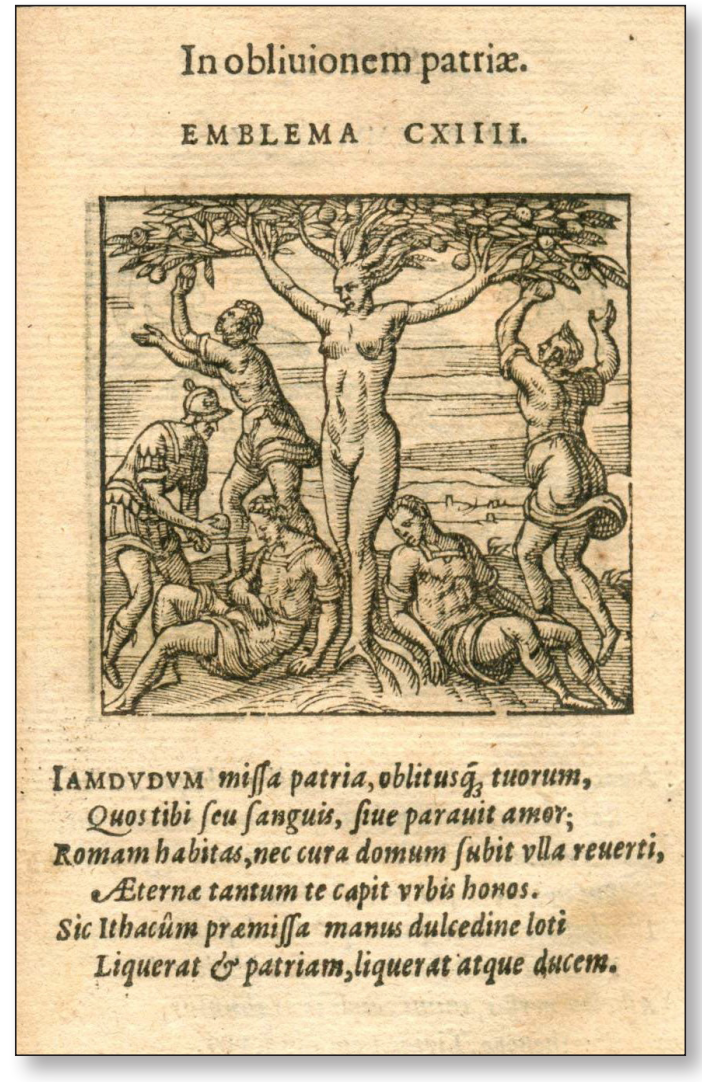

Fig. 3. Andrea Alciato, Emblemata, Amberes, 1608. Emb. 114.

También deseables formas femeninas adquiere, como de todos es sabido, la sirena -«[...] mujer seductora, que acaba en oscuro pez, como muchos monstruos que trae consigo el deseo", indica el propio Alciato-, que arrastra con sus cantos y acordes a la embarcación de Ulises hacia los mortales acantilados en un tercer emblema de nuestro humanista italiano (Sebastián López, 1985: 152-153). ${ }^{25}$ Vale la pena reproducir a continuación algunos de los

\footnotetext{
24. Emblema 114: In oblivionem patriae («Sobre el olvido de la patria»). La configuración femenina del tronco puede responder también al hecho de que, según las Metamorfosis de Ovidio (IX, 340 y ss.), la ninfa Lotis fue convertida en un arbusto de flores rojas llamado loto.
}

25. Emblema 115 (ed. 1608): Sirenes («Las sirenas»). 
comentarios «magistrales» que Diego López compone para clarificar el significado moral de este mito universal:

«Eran [las sirenas] muy diestras, una en música de voz, otra en tañer una flauta, la tercera en tocar una cíthara, o vihuela, con tanta gracia que ninguno las oía que no quedase arrobado de tanta melodía, y dulçura. Tenían tan grande astucia, que siempre tañían, y cantavan lo que mas conformava con el gusto de los oyentes. Si querían caçar a los enamorados, cantavan cosas de amores. Si a los valientes, hazañas. Y desta manera a todos los demás. Y al que cogían lo matavan $[\ldots] »(1615: 1285 \mathrm{v})$.

En cuanto a la etimología de los nombres atribuidos a estos astutos seres, indica:

«Parthénope significa virgen, de donde las rameras sabiendo que los hombres son aficionados a las donzellas, o por lo menos a las mugeres castas, y honestas, se fingen ellas tales, teniendo los ojos mesurados, y puestos en tierra, y fingen que tienen verguença en oyendo qualquiera palabra amorosa, y no consienten que a la primera vista las toquen, ni lleguen la mano, para que desta manera hagan que las deseen, para cogerlos en sus redes. Leucosia significa blancura, significando la limpieza del alma, que fingen las malas mugeres para cubrir sus enredos, y artificiosos embustes, porque assí como las cosas hechas con arte son más apazibles, quando no se ve la cautela, así son enfadosas si se entiende. Ligia significa círculo, dando a entender los lazos con que tienen enredados a los miserables amantes" (1615: 288r).

Ulises, permanente modelo de hombre prudente para la mentalidad renacentista, conocedor del grave peligro que estas criaturas representan para la seguridad de su embarcación, ordenó a sus compañeros que se tapasen los oídos con cera en tanto él, en su deseo de experimentar los efectos de tan embriagadora música, se hizo amarrar al mástil del navío de modo que pudiera someterse al hechizo sin riesgo alguno para la tripulación; según una versión de la leyenda, las sirenas, despechadas por su fracaso, se arrojaron al mar transformándose en peñascos. Tal astucia del héroe itacense significa, según Alciato, «[...] que los doctos no tienen nada que hacer con las putas», en una exaltación de la abstinencia ante la provocación femenina, cualidad que será muy apreciada en la literatura moral de estas centurias como síntoma de sabiduría y virtud.

Son abundantes los emblemas que, como el de Alciato, recurren al motivo de la sirena como aviso perentorio frente al acecho de los pecados carnales. ${ }^{26}$ Baste como botón de muestra el epigrama que Sebastián de Covarrubias compone para su emblema dedicado al sensual híbrido:

«El vicio de la carne, es una dama,

Del medio cuerpo arriba muy hermosa,

Del medio abaxo, pez, de dura escama

Orrenda, abominable, y espantosa:

Con halagos os llama, y con su llama

Abrasa, y quema, aquesta semidiosa,

Por tal tenida entre los carnales,

Princesa de las furias infernales» (1610: I, emb. 94) [fig. 4]..$^{27}$

26. Sobre este particular puede consultarse la completa panorámica trazada por R. Lamarca Ruiz de Eguílaz (1997). Vid. también al respecto Bernat y Cull, (1999: entradas 1500 a 1505, 726-728); Escalera Pérez, 2000: 787; Agudo Romeo (2004: 110-111; 2008a: 2778-2781) y D'Onofrio (2016: 35-37).

27. Atrum desinit in piscem ("Acaba en [forma de] negro pez»), fol. 94r.

IMAGO, NÚM. 10, 2018, 7-52 


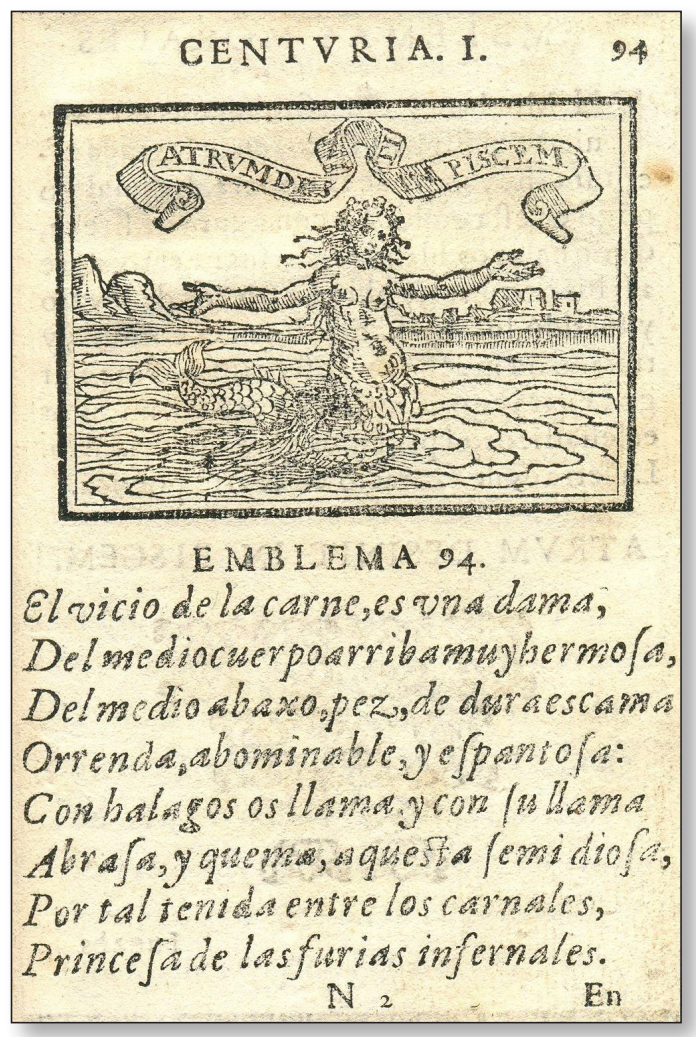

Fig. 4. Sebastián de Covarrubias, Emblemas morales, Madrid, 1610. Cent. I, emb. 94.

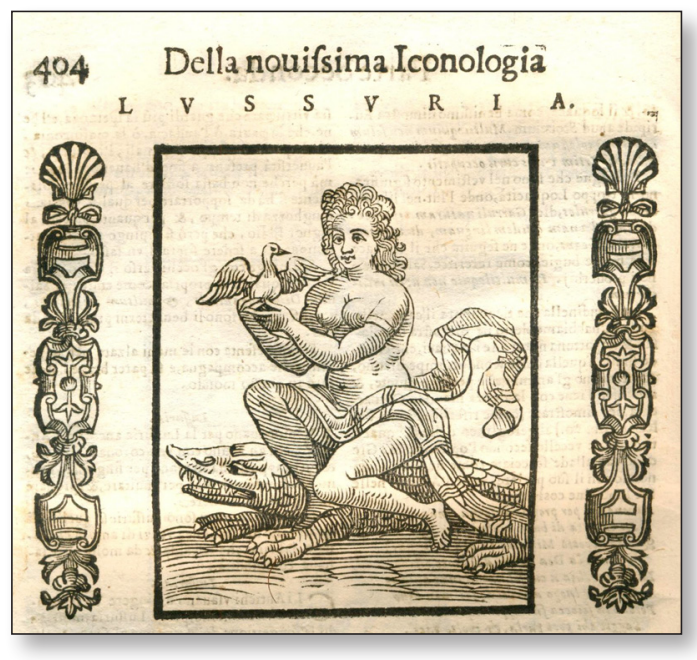

Fig. 5. Cesare Ripa, Della Novissima Iconologia, Padua, 1625. II parte, p. 404.

En perfecta sintonía con estos emblemas, la alegoría de la Lujuria es caracterizada de igual modo como una seductora figuración femenina. Según Cesare Ripa [fig. 5], debe representarse como

«Una joven que lleva muy rizados cabellos que han de estar además artificiosamente ondulados. Irá casi desnuda, mas el paño con que cubre sus partes habrá de estar compuesto de diversos colores. Será hermosa a la vista, apareciendo sentada sobre un cocodrilo, ${ }^{28}$ llevando entre las manos sujeta una perdiz ${ }^{29}$ a la que está acariciando".

Parece que a Ripa no le preocupan tanto las consecuencias morales de los efectos de la Lujuria, como la desestabilización que éstos pueden provocar en el statu quo vigente:

«La Lujuria es un ardiente y desenfrenado apetito de la carnal concupiscencia, sin observancia de leyes ni de lo que impone Natura, sin mostrar respeto alguno por el sexo ni por los órdenes o estados» (1625: II, 403; 1987: II, 33).

Entre las consecuencias negativas directas que los varones pueden padecer a causa de los vínculos amorosos ilícitos o inconvenientes, se encuentra, en primer lugar -no olvide-

28. "Aparece sentada sobre un cocodrilo porque ya decían los Egipcios que dicho animal era símbolo de Lujuria, en atención a su carácter fecundísimo, pues en efecto engendra muchos hijos», añade Ripa (1625: II, 404; 1987: II, 34). Vid. también Valeriano (1567: XXIX, 207r).

29. «[...] sostiene y acaricia una perdiz entre las manos por no haber cosa más conveniente para mostrar libidinosidad y desenfrenadísima lujuria que la indicada perdiz; la cual muy a menudo, agitada por la rabia y el deseo del coito, se enciende en tal lujuria que incluso llega el macho a destrozar los huevos que incubara la hembra, cuando está en incubar entretenida, viéndose así impedido de unirse a su pareja», explica Cesare Ripa (1625: II, 404; 1987: II, 34). Vid. igualmente Valeriano (1567: XXIV, 175v). 
mos que la Emblemática fue generada por la intelectualidad humanista-, el abandono repentino de los estudios o de la posición académica alcanzada con tanto esfuerzo. Alciato ejemplifica esta circunstancia mediante la imagen de un hombre maduro y docto en diversas disciplinas -derecho, retórica...-, sentado en un noble escaño y rodeado de tres divinidades clásicas: Marte, alegoría de las armas, Palas Atenea, encarnación de las letras, y Venus, acompañada de Cupido, símbolo del amor camal; de entre las tres personificaciones, el catedrático escoge a la tercera, en una escena similar a la del Juicio de Paris, ${ }^{30}$ simbolizando así su debilidad y servidumbre a las más bajas pasiones (Sebastián López, 1985: 143144). ${ }^{31}$ Esta composición fue consagrada «[...] a los letrados, y estudiantes, los quales por dar en ser enamorados dexan los estudios, los quales impiden con la fuerça de los amores, por causa de los quales hemos visto muchos ingenios perdidos» (López, 1615: 272r). Pero más grave es aún la pérdida de la honra, la autoestima, o incluso la vida, cuando la pasión amorosa desenfrenada florece en la edad senecta: el anciano Sófocles logró obtener con dinero el favor de la joven y bella Arquipe, seducción que costó al trágico griego las murmuraciones de sus conciudadanos y su pronto fallecimiento. ${ }^{32}$ El grabado del correspondiente emblema de Alciato [fig. 6] muestra al poeta acariciando el pecho de su complaciente compañera, en tanto al fondo se distingue el cadáver desnudo de un hombre, tendido en el suelo, sobre el que se ha posado un búho, ave portadora, como la joven amante, de funestos presagios (Sebastián López, 1985: 153-154)..$^{33}$

30. El troyano Paris, joven de extraordinaria belleza y gran valor, protagonizó uno de los más célebres episodios míticos clásicos, causante en último extremo de la guerra de Troya: las diosas Atenea, Hera y Afrodita, tras una disputa mantenida en el Olimpo, se presentaron ante el héroe troyano en el monte Ida, donde pastoreaba un rebaño de cabras, para que éste actuase como árbitro a la hora de pronunciarse sobre cuál de ellas era la más hermosa. Para ganarse su favor en el Juicio, cada una de ellas, por turno, le ofreció su protección y determinados dones: Hera le prometió el imperio de toda Asia, Atenea la prudencia y la victoria en sus combates, y Afrodita el amor de Helena de Esparta. La decisión de Paris favoreció a la tercera de las aspirantes, entregando a la diosa del amor la manzana de oro que simbolizaba su triunfo (Grimal, 1989: 408-409, s. v. «Paris»).

31. Emblema 108 (ed. 1608): In studiosum captum amore ( Sobre el estudioso atrapado por el amor»).

32. «Ninguna cosa hay -indica Diego López (1615: 289r y v)-porque querer un viejo darse a la luxuria, porque es querer dos vezes ser mancebo, y lo que peor es que parece mal a todo el mundo, fuera de todo esto es causa de que muera, y assí los viejos que se casan con mugeres moças viven poco tiempo".

33. Emblema 116 (ed. 1608): Senex puellam amans ("Del viejo que ama a la muchacha»).

IMAGO, NÚM. 10, 2018, 7-52 
Como hemos podido constatar en algunos de los emblemas y comentarios anteriores, muy estrechamente vinculado al tema de la seducción femenina emerge de inmediato el fantasma de la prostitución. La ramera -personaje por lo demás habitual en la novela picaresca hispana-fue considerada en el Antiguo Régimen como un mal necesario que era preciso mantener bajo cierto control. Junto a las circunstancias que a lo largo de la historia han favorecido el arraigo y desarrollo de la práctica de· la prostitución -miseria, degradación de las costumbres, escasa cultura general...-, durante los tiempos modernos adquirirá un especial protagonismo un nuevo factor que ya conocemos: la acuciante necesidad de mantener íntegra la honestidad de la mujer familiar. Ante la sobredimensionada importancia que se concedió a las relaciones sexuales prematrimoniales o adúlteras, se comprende que resultara necesaria la disponibilidad de meretrices sobre las que el varón pudiera descargar sus ansias reprimidas. De este modo, la prostitución fue tolerada por la sociedad de estas centurias como una protectora de la institución matrimonial al actuar como salvaguarda de la integridad moral de las restantes mujeres, y permitir a los ciudadanos una convivencia más pacífica (Fernández Álvarez, 1989: I, 193; Testón Núñez, 1985: 192). Sin embargo, el tono formativo que se exige a la Emblemática obligó a sus cultivadores a arremeter contra las rameras sin medias tintas, con todas sus armas dialécticas, a la hora de exacerbar los aspectos más sórdidos de su profesión o las consecuencias de su trato. Andrea Alciato compuso también varios emblemas dedicados de forma explícita a esta práctica, recurriendo para ello una vez más, no a casos reales de su tiempo, sino a diversas personalidades míticas, bíblicas o a motivos tomados del mundo natural, que permiten transformar a las prostitutas en feroces criaturas que seducen y destruyen a los incautos e inexpertos jóvenes que se dejan atrapar entre sus garras.

Un primer ejemplo nos lo proporciona la maga Circe, hermana del rey de Cólquide, que habitaba en la isla de Ea. Esta hechicera, si seguimos el relato de la Odisea (X, 133-574), transformó mediante encantamiento a los compañeros de Ulises en animales diversos -cerdos, leones, perros...- de acuerdo con la tendencia profunda del carácter y naturaleza de cada uno, y los condujo hacia unos establos ya repletos de otras bestias metamorfoseadas en ocasiones anteriores; tan sólo Ulises -el prudente- pudo escapar al hechizo, gracias a la ingestión de una hierba mágica que le proporcionó el dios Hermes. En el emblema que Alciato dedica a este episodio [fig. 7], Circe representa a la ramera que transforma a sus amantes en bestias irracionales -los hombres "carnales, viciosos y deshonestos"- (Sebastián López, 1985: 111-112); ${ }^{34}$ y de nuevo Ulises, que, gracias a la ayuda divina, «no se muda en animal bruto», es encarnación del «[...] hombre firme, el sabio, y constante, que ni puede ser quebrantado con algunos espantos, ni con algunos halagos puede ser apartado de lo honesto" (López, 1615: 213r). Otro emblema, esta vez de inspiración bíblica, nos muestra en el grabado a una prostituta coronada y vestida con noble atuendo, que cabalga sobre una monstruosa bestia de siete cabezas y diez cuernos al tiempo que presenta a una muchedumbre ebria, postrada ante ella, una rica copa dorada. La imagen [fig. 8] se inspira directamente en el tema apocalíptico de la visión de la Gran Prostituta de Babilonia, ${ }^{35}$ objeto de una prolongada iconografía que se remonta a las ilustraciones de los Beatos altomedievales:

34. Emblema 76 (ed. 1608): Cavendum a meretricibus ( Que hay que guardarse de las rameras»); vid. Escalera Pérez, 2000: 785 .

35. "Y vi una mujer, sentada sobre una Bestia de- color escarlata, cubierta de títulos blasfemos; la Bestia tenía siete cabezas y diez cuernos. La mujer estaba vestida de púrpura y escarlata, resplandecía de oro, piedras preciosas y perlas; llevaba en su mano una copa de oro llena de abominaciones, y también las impurezas de su prostitución, y en su frente un nombre escrito -un misterio-: "La Gran Babilonia, la madre de las rameras y de las abominaciones de la tierra» (Ap 17, 3-5). Vid. al respecto García Arranz, 2001. 


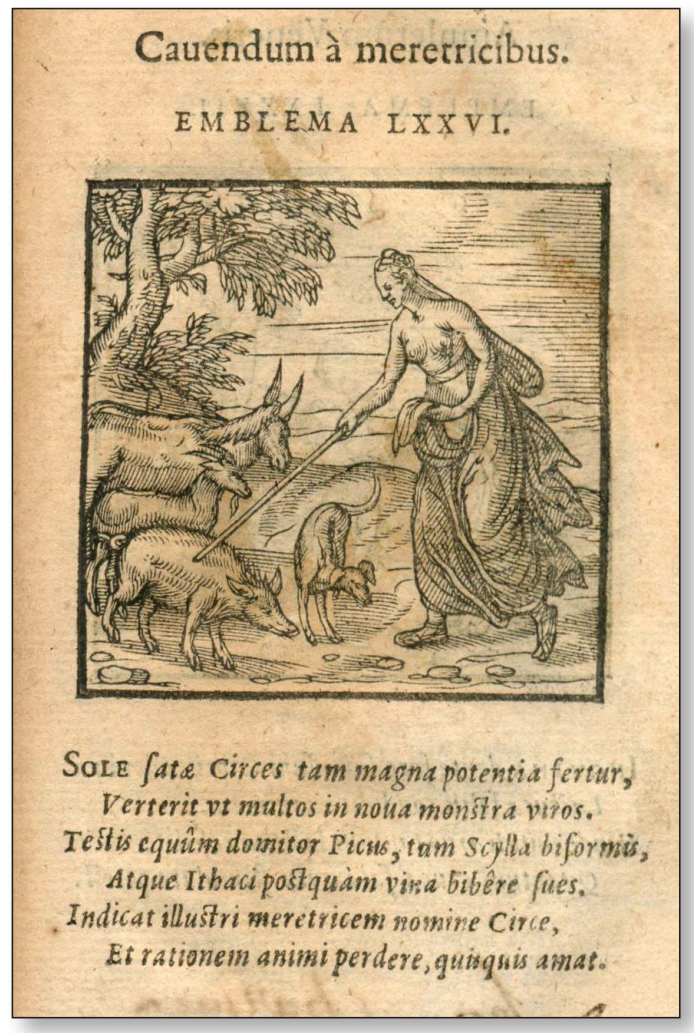

Fig. 7. Andrea Alciato, Emblemata, Amberes, 1608 Emb. 76

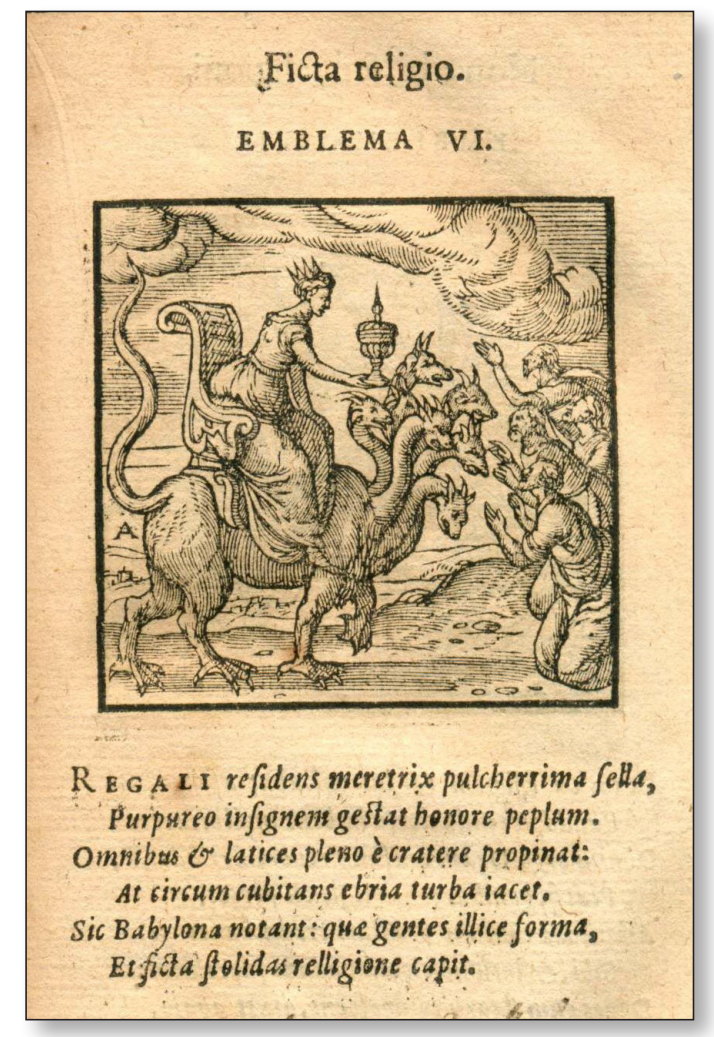

Fig. 8: Andrea Alciato, Emblemata, Amberes, 1608. Emb. 6.

«Así pintan a Babilonia -señala el emblemista-, que atrapa a las gentes estúpidas con una belleza seductora y una religión falsa" (Sebastián López, 1985: 34-36). ${ }^{36}$ Aquí la figura de la ramera escapa a sus habituales consideraciones morales para adquirir una fuerte dimensión contrarreformista: representa a las corrientes protestantes que "[...] han engañado a muchos dándoles a bever doctrina errónea como de vaso dorado fingiendo sanctidad, y como embriagados han menospreciado la fuente de la sana cathólica doctrina y se han quedado postrados [...]" (López, 1615: 29v).

Ya adelantamos que no faltan ejemplos en los que las mujeres de placer adquieren el aspecto de temibles bestias al acecho de sus indefensas víctimas. Una leona está a punto de atrapar entre sus zarpas a un carnero en una representación en relieve que adorna el sepulcro de una célebre prostituta de la Antigüedad, Lais de Efira, en otra de las picturae emblemáticas de Andrea Alciato (Sebastián López, 1985: 109-110) [fig. 9] ${ }^{37}$ Esta escena simboliza el modo en que la ramera tenía "agarrados» por las nalgas a sus amantes, que no son más que un rebaño de "carneros". También Alciato se hace eco en otro de sus emblemas de un. curioso relato de la literatura zoológica antigua, según el cual el pez sargo siente una fer-

36. Emblema 6 (ed. 1608): Ficta religio ( La religión falsa»).

37. Emblema 74 (ed. 1608): Tumulus meretricis («La sepultura de la ramera»). Vid. Escalera Pérez, 2000: 784; Agudo Romeo (2008a: 2781-2782; 2008b: 133-137)

IMAGO, NÚM. 10, 2018, 7-52 


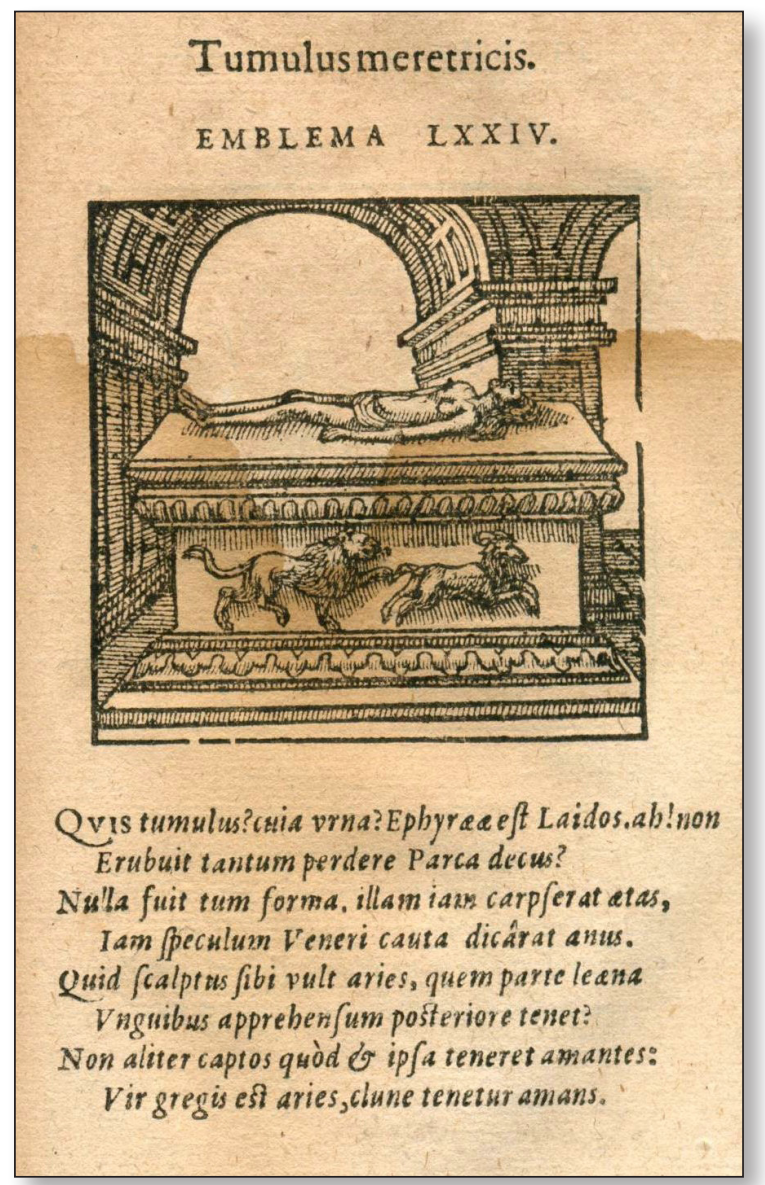

Fig. 9. Andrea Alciato, Emblemata, Amberes, 1608. Emb. 74. viente pasión amorosa por las cabras, a las que puede contemplar cuando pacen en las orillas del mar. Algunos pescadores, conocedores de esta singular devoción, se cubren con pieles y cuernos caprinos para atraer a los pescados hasta sus embarcaciones, y capturarlos sin dificultad en las redes. ${ }^{38}$ "La cabra escribe el milanés- simboliza a la ramera, y es el sargo semejante al amante, que, desdichado, perece atrapado por un amor inmundo" (Sebastián López, 1985: 110-111). ${ }^{39}$ Un caso similar lo ofrece la pantera, animal que, según el relato difundido por medio de los bestiarios medievales, tras comer copiosamente y hacer la digestión con un reparador sueño de tres días, procede a difundir su aliento perfumado entre las demás criaturas; constituye de este modo una alegoría de Cristo resucitado, que propaga su suave mensaje entre los fieles. Sin embargo, al trasladarse a algunos libros de emblemas, la historia experimenta cambios radicales: la pantera utiliza su suave aroma para atraer a diversos animales con el fin de capturarlos y devorarlos con facilidad, al tiempo que oculta su cabeza entre unos matorrales para que sus víctimas no descubran su verdadera natu-

raleza y propósitos hasta el último momento [fig. 10]; simboliza aquí el temible felino a la mujer lasciva que seduce a los jóvenes inadvertidos mediante sus aparentes y engañosos encantos (Camerarius, 1654a, emb. 37). ${ }^{40}$

No queremos pasar por alto en este apartado otros dos exempla procedentes del mundo vegetal. En primer lugar la hiedra, planta trepadora que envuelve los troncos de los

38. Según escribe Claudio Eliano (De an I, 23): «Sea por lo que sea, [los sargos] sienten una enorme atracción por las cabras [...] En fin, como están locamente encariñados con las cabras, son víctimas de lo mismo que pretenden. En efecto, el pescador se cubre bien con una piel de cabra con cuernos y todo, una vez desollada [...] A continuación esparce por el agua del mar, bajo la cual habitan los peces antes citados, harina remojada en caldo de carne de cabra. Y los sargos, atraídos por el olor antes mentado como si fuera un hechizo amoroso, se acercan, y al tiempo que comen la harina resultan fascinados por la citada piel. Entonces, el pescador coge cantidad de ellos con un anzuelo fuerte y con un sedal de hilo blanco» (Claudio Eliano, 1989: 46).

39. Emblema 75: In amatores meretricum ( $S$ Sobre los que aman a las rameras»); la trad. es de Pilar Pedraza. Vid. Escalera Pérez, 2000: 784. Coincide Diego López (1615: 210v) en considerar que el sargo representa a los jóvenes, "[...] porque aquella edad es la más fácil de ser engañada con el apetito sensual, y porque tiene poca experiencia». 40. Allicit ut perimat ("Tienta a la destrucción»), fols. 45r y v. También Pierio Valeriano (1567: XI, 83v-84r) entiende que la pantera representa, entre otros significados jeroglíficos, al hombre que disimula sus vicios. 
árboles o cubre los muros hasta secar los primeros y derribar los segundos a causa del efecto destructivo de sus raíces aéreas, constituye también una sencilla metáfora de la prostitución, ampliamente utilizada por los autores de tratados emblemáticos. ${ }^{41}$ Juan de Horozco, que dedica un emblema a la imagen de la planta enroscada en tomo al tronco y las ramas de un árbol muerto, bajo el lema Enecat ample$x u$ ("Mata con su abrazo»), explica su sentido con los siguientes versos:

\begin{abstract}
«El árbol que consiente compañía de la yedra lasciva y halagüera gastando su virtud de noche y día entre sus braços es forçoso muera: porque veáys qué haze quien se fía de la falsa amistad de la ramera, que le consume y gasta sin medida honra, salud, hazienda, sangre, y vida» (1603/1604: III, emb. 18). ${ }^{42}$
\end{abstract}

Por su parte Hernando de Soto, «Contador y Veedor de la casa de Castilla de su Magestad" al tiempo que emblemista, recurre a la adelfa en flor [fig. 11], "Que a la vista es apacible / Pero al gusto venenosa", para lanzar la siguiente advertencia: «Aborrecerás las [adúlteras y rameras], y conocerás que son qual la rosa de la Adelfa, que de su belleza engañados los simples y rudos animales llegan a comerla, y como tiene encubierto el veneno, mueren luego que acaban de comer» (1599: emb. 42). ${ }^{43}$

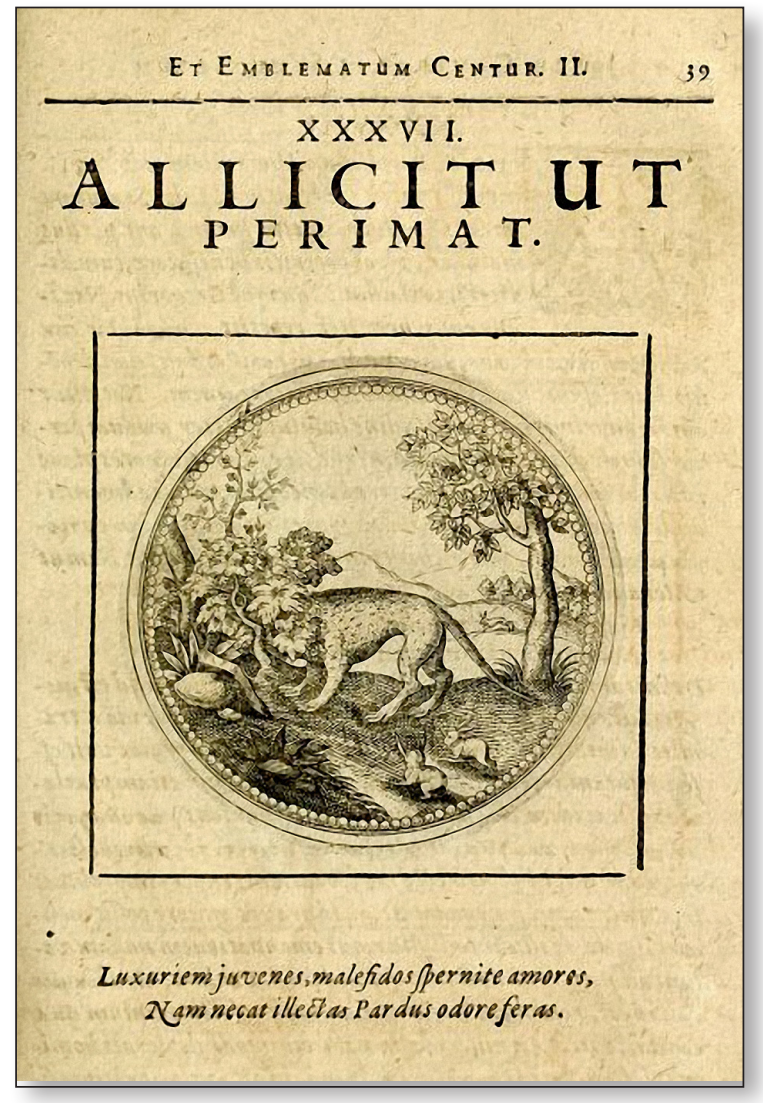

Fig. 10. Joachim Camerarius, Symbolorum et emblematum ex animalibus quadrupedus, Franckfurt am Main, 1654. Emb. 37.

41. Sobre los diversos significados simbólicos de la hiedra puede consultarse el comentario de R. García Mahíques (1988: 82-84).

42. Fol. 136r. Vid. Escalera Pérez, 2000: 785-786; Agudo Romeo, 2004: 110; 2008a: 2783-2784). Sebastián de Covarrubias, que recurre a un emblema muy similar en su libro (1610: I, emb. 37, Meretricis amplexus - «La caricia de la prostituta»-, fols. $37 \mathrm{r}$ y v), escribe sobre este motivo: «La yedra es symbolo de la ramera, por quanto al que coje entre sus braços, al parecer amorosos no le suelta hasta que le ha consumido honra, hazienda, salud y vida ... Muéstranos su hoja verde, que es la edad florida, y la hermosura, pero el reverso della es amarillo, color mortal, y su gusto amargo".

43. Meretricum fallacia ( «El engaño en la mujer»), fols. 88r a 89v. Vid. Escalera Pérez, 2000: 786-787; García Arranz y Pena Sueiro, 2017: 217-219.

IMAGO, NÚM. 10, 2018, 7-52 


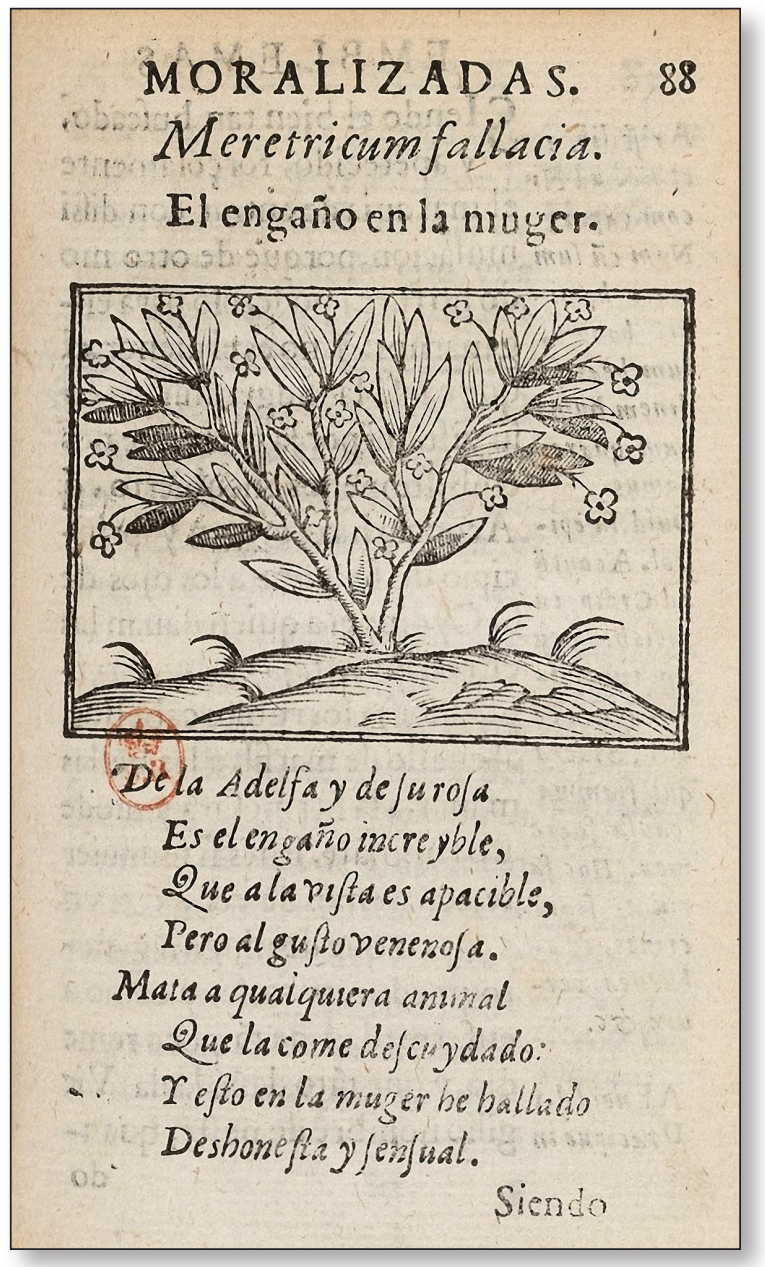

Fig. 11. Hernando de Soto, Emblemas moralizadas, Madrid, 1599. Emb. 42.

\section{EL MATRIMONIO: CRISOL DE LIMITACIONES Y DEFECTOS DEL GÉNERO FEMENINO}

Las directrices emanadas del Concilio de Trento y de los sínodos posteriores potenciaron la rehabilitación del matrimonio como sacramento monógamo e indisoluble. Sin embargo, el estado matrimonial, considerado por los moralistas «peligroso» e inferior al de la virginidad o el celibato de los religiosos, ${ }^{44}$ dista mucho de ser la situación perfecta para el varón. Siempre existe el riesgo de la lujuria, no sólo en acto sino también en el pensamiento, pues toda la concepción eclesiástica sobre la sexualidad, en especial la conyugal, se construye sobre un complicado código al que son sometidas tanto las acciones ya cometidas como las intenciones y los deseos. Además, el hombre debe ser consciente de que el matrimonio es, en muchas ocasiones, un «negocio arduo» destinado a durar toda la vida; esa es la razón por la que Járava del Castillo, con una finalidad claramente disuasoria, advierte al futuro esposo de que las mujeres son «miserables, avarientas, cuitadas, mecánicas y otras mal acondicionadas, soberbias, celosas, vocingleras y poco cuidadosas del gobierno de sus casas» (Járava del Castillo, 1675; en Hernández Bermejo, 1990: 60). Llega incluso a entenderse la unión conyugal como una "pesada carga" o "atadura" que aprisiona al varón, ligándole a su pareja hasta la muerte ${ }^{45}$ tal y como se pone de manifiesto en la literatura simbólica, e incluso en los ceremoniales del momento, donde no faltan alusiones explícitas a «lazos», «nudos», «yugos»

44. El emblemista Francisco de Villava (1613: I, 59v), basándose en el capítulo séptimo de la primera Epístola de San Pablo a los Corintios sobre matrimonio y virginidad, escribe al respecto: "Si a los que professan Virginidad, virtud tan amada de Christo, y tan agradable al Cielo, les diere alguna vez cuydado, ver que aunque es estado más alto que el del matrimonio, carecen de fructo y sucessión de hijos, que los imiten y hereden, pongan los ojos en que también ay multiplicación espiritual, tanto más honrosa y apetecible, quanto es el espíritu más aventajado que la carne $[\ldots] »$.

45. Se llega a argumentar que el matrimonio fue concebido para el hombre como una tortura dispuesta por Dios para que expiara el pecado original (Anderson y Zinsser, 1991: II, 115). 
o «cepos». El portugués Tomé Pinheiro da Veiga escribe al respecto de la celebración del matrimonio practicada por los españoles:

«Usan en los casamientos de las antiguas velaciones, y después de desposados los novios, van a la iglesia por las bendiciones. En la misa están con un velo sobre la cabeza, razón por la cual los llaman 'velados', además de una cinta de seda que los tiene como ligados y juntos. Acabadas las oraciones, échales el cura la estola, a manera de yugo, al pescuezo, y con la misma les echa después un nudo a las manos». ${ }^{46}$

Por su parte, el iconólogo Cesare Ripa describe así su personificación del «Matrimonio» [fig. 12]:

«Joven pomposamente ataviado y vestido, que lleva al cuello un yugo y los pies en un cepo; ha de tener un anillo o alianza de oro colocada en el dedo, sujetando además un membrillo en la mano, y aplastando con los pies una víbora.

Tanto el yugo como el cepo simbolizan que el Matrimonio es peso tan gravoso para las fuerzas del hombre, que le impide caminar con libertad en orden a la realización de numerosas acciones, dado que el casarse es como venderse uno mismo, obligándose bajo una ley perpetua» (1625: II, p. 409; 1987: II: 47).

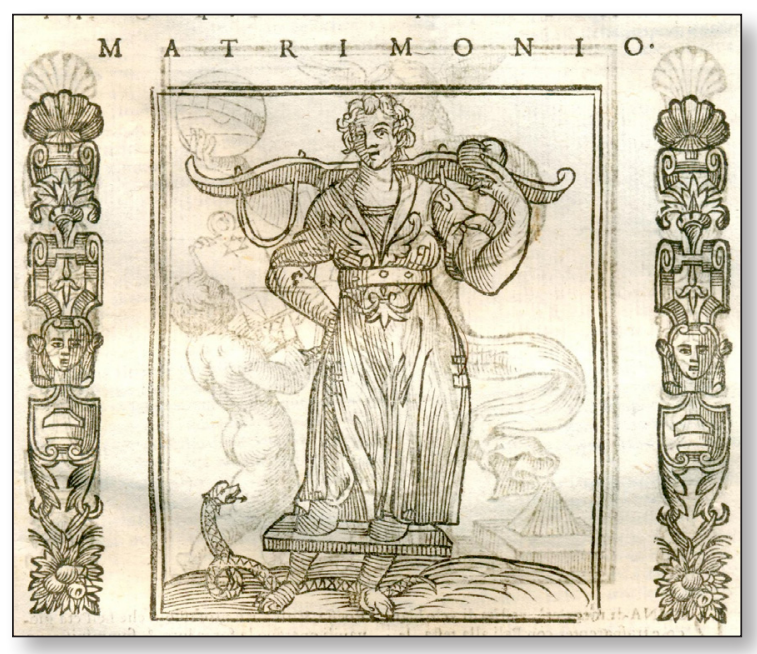

Fig. 12. Cesare Ripa, Della Novissima Iconologia, Padua, 1625, II parte, p. 409.

Si bien en las siguientes líneas esgrime algunas razones -nos provee, por ejemplo, de herederos para nuestros bienes y fama, y nos concede honor y crédito en nuestro entorno social, al tiempo que nos permite "gozar lícitamente de los placeres de Venus»-que hacen del compromiso matrimonial una opción "apreciada y deseable» a pesar de sus ataduras.

Ejemplos de similar catadura aparecen incluidos en el género emblemático. En el tratado de Sebastián de Covarrubias encontramos la imagen de una dama y un caballero, noblemente ataviados, que estrechan sus respectivas manos derechas en tanto sobre sus cabezas aparece suspendido un gran yugo con una cuerda entrelazada; a sus espaldas se abre un paraje rural en el que puede observarse a un labrador conduciendo con su vara una yunta de bueyes, en clara alusión a los trabajos que conlleva el sacramento aludido [fig. 13]. El emblemista indica en el epigrama:

«En quanto el pan se come de la boda,

Notable es el contento, y alegría,

De los casados y su gente toda

Gastando en regozijos, noche y día:

Mas quando se recoge, y acomoda

46. Pinheiro da Veiga, T., Fastiginia ou fastos geniaes tirados da tumba de Merlín, onde forao echados con a demanda do Santo Brial pello arçobispo Turpino, manuscrito en la British Library de Londres; el fragmento traducido se encuentra en García Mercadal, 1959: 141, y Díez Borque, 1990: 86. 


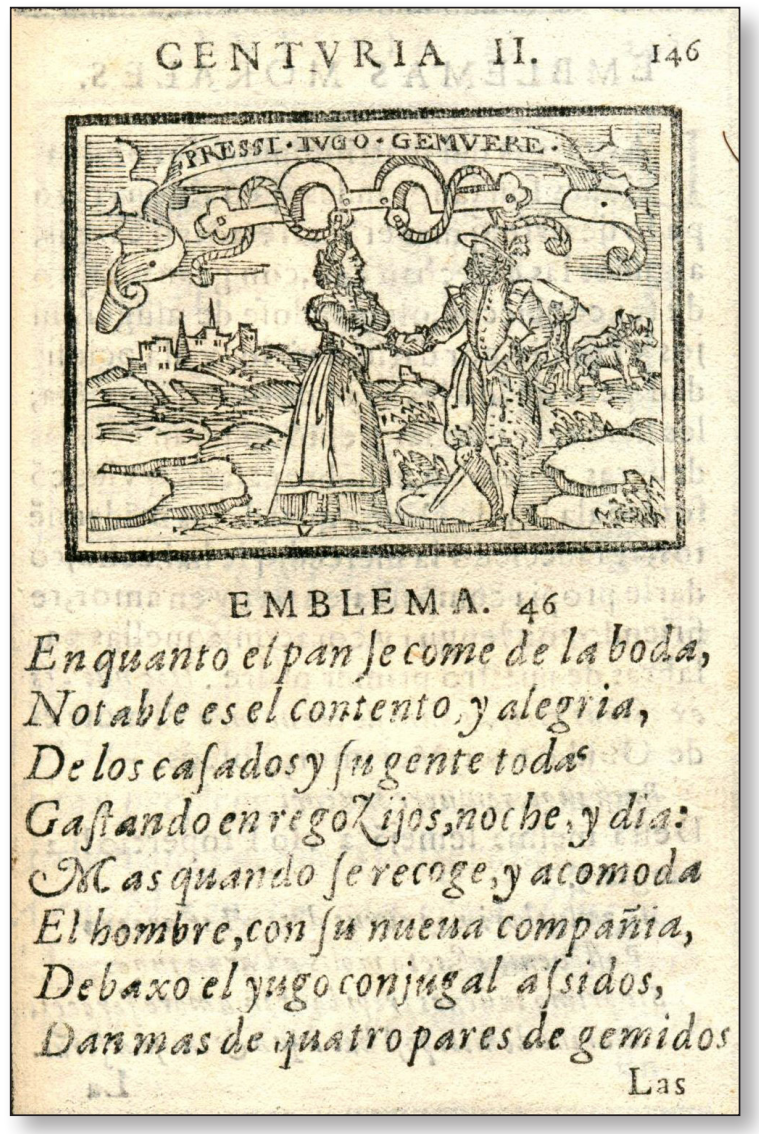

Fig. 13. Sebastián de Covarrubias, Emblemas morales, Madrid, 1610. Cent. II, emb. 46.
El hombre, con su nueva compañía, Debaxo el yugo conjugal assidos, Dan más de quatro pares de gemidos (1610: II, emb. 46). ${ }^{47}$

Añade en la correspondiente declaración:

«Las cargas del matrimonio y sus obligaciones son tan grandes, que con alguna razón pudo decirse, que más eran carretadas que cargas, algunos las desechan de sí, con gran peligro de sus conciencias, olvidándose de muger, hijos y familia, por darse al vicio, y a la ociosidad, pero quando les ayan de tomar la cuenta, les harán cargo dellas, y entonces serán pesadas de veras" (1610: II, fol. 146v).

Cuando se elaboran emblemas destinados a caracterizar los aspectos «no negativos» de la convivencia matrimonial, no inciden en sus bondades intrínsecas -como hiciera Cesare Ripa-, sino en la necesidad de mantener su estabilidad, a través del cultivo de valores como la fidelidad, la templanza y la mutua complacencia por parte principalmente, como era de esperar, del componente femenino.

Para ilustrar su emblema In fidem uxoriam ( «Sobre la fidelidad de las esposas»), Andrea Alciato representa a una dama y a su compañero sentados uno junto al otro, mirándose a los ojos al tiempo que estrechan sus manos, acompañados de un perrillo y a la sombra de un manzano, pues animal y fruta son, de acuerdo con abundantes testimonios literarios, símbolos de lealtad y amor recíproco (Sebastián López, 1985: emb. 190, 234-235; Agudo Romeo, 201 1: 103-4; 2008a: 2785-2786). En cuanto a la «conformidad y unión de los casados»-situación que agrada a Dios y proporciona la mayor felicidad a los hombres, tal y como nos recuerda Hernando de Soto-, este emblemista recurre a la representación figurada de la constelación de Géminis, o, lo que es lo mismo, a la imagen de los míticos Dioscuros, Cástor y Pólux, hijos de Zeus, abrazados en el firmamento, pues ambos hermanos guerreros fueron símbolo de permanente concierto en todas sus acciones (1599: emb. 57). ${ }^{48}$ Recrea-

47. Pressi iugo gemuere ("Gimieron bajo la presión del yugo»), fol. 146r. Vid. Agudo Romeo, 2011: 110 -111.

48. Optimum matrimonium ( «El Matrimonio que es bueno»), fol. 120r. El propio Soto se muestra opuesto, en otro momento de su obra (1599: emb. 25, fol. 51r) al matrimonio forzado, a causa de los graves trastornos que provoca en los cónyuges, coincidiendo así con la opinión de otros moralistas. Emplea para ello la figura de dos serpientes entrelazadas entre sí, bajo el mote Violentum matrimonium ( El matrimonio forçado»): "Este lazo perpetuo [del matrimonio] [...] requiere para tener el efecto devido, libre consentimiento y voluntad [...] que no puede aver mayor tormento, que el estar un hombre, o una muger casados, sin gusto». Vid. Escalera Pérez, 2000: 770-

IMAGO, NÚM. 10 2018, 7-52 
ción fabulística del mutuo respeto entre los esposos es el fantástico relato de la víbora y el pez morena que, según los textos zoológicos antiguos, protagonizan encuentros amorosos en la orilla del mar, no sin antes vomitar sus venenos para propiciar una feliz unión. ${ }^{49}$ Alciato escogió esta supuesta propiedad del pez y el reptil para subrayar que "Se debe al tálamo el máximo respeto: el cónyuge debe al cónyuge recíprocos favores» (Sebastián López, 1985: 235236). ${ }^{50}$ Tal necesidad de equilibrio y concordia matrimonial alcanzó su más poética expresión en la imagen de la vid y el olmo seco entrelazados, encamación del amor o la amistad que perdura incluso después de la muerte, tal y como pusieron de manifiesto Andrea Alciato (Sebastián López, 1985: 201 202) [fig. 14] $]^{51}$ y otros emblemistas o literatos como Francisco de Quevedo. ${ }^{52}$

La receta para conseguir estas fidelidad y conformidad maritales nos la proporciona Otto van Veen en su emblema titulado Frugalitas exemplar ( Ejemplo de la templanza») (Veen, 1701: emb. 32, 64-65), cuya imagen presenta a dos esposos plácidamente recostados en su lecho, relajados y ajenos a cualquier inquietud, en el interior de una sobria estancia, junto a una mesa con frugales alimentos. Fuera de los sólidos muros

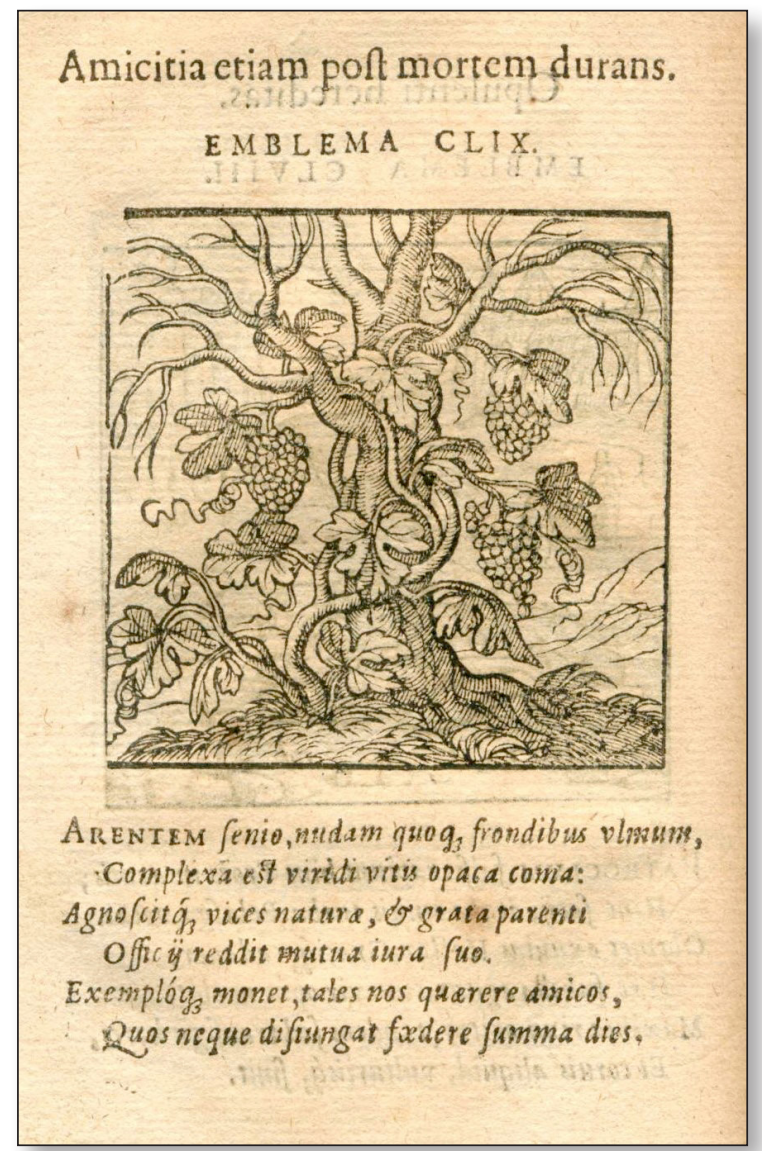

Fig. 14. Andrea Alciato, Emblemata, Amberes, 1608. Emb. 159.

771; Mínguez Cornelles, 2010: 259-260; Agudo Romeo, 2011: 116; García Arranz y Pena Sueiro, 2017: 166 -168 y 262-264.

49. Escribe Plinio sobre este episodio animalístico: "Cree el vulgo que [las morenas] se deslizan a tierra seca y quedan preñadas al copular con serpientes», Nat. hist. IX, 76 (Plinio el Viejo, 2003: 275-276; vid. también Pierio Valeriano (1567: XXIX, 209r).

50. Emblema 91 (ed. 1608): Reverentiam in matrimonio requiri ("Que el matrimonio requiere respeto»); la trad. es de Pilar Pedraza. Vid. Escalera Pérez, 2000: 773-774; Agudo Romeo, 2011: 106. Diego López (1615: 442r) aprovecha el comentario del emblema para ratificar quién debe llevar la voz cantante en este concierto matrimonial: «Ni más ni menos la muger no piense que ha de ser la cabeça de casa, ni de su marido, sino compañera, y por esto dizen algunos autores (como se refiere en el catecismo Romano) que no formó Dios la muger de la cabeça, ni de los pies de Adán, porque no avía de ser la cabeça del marido, ni tan poco los pies, para traerla arrastrando, ni por el suelo, sino estimarla como compañera suya, y por esta causa la formó Dios del lado de nuestro primer padre Adán, y no de la cabeça, ni pies».

51. Emblema 159 (ed. 1608): Amicitia etiam post mortem durans ( LLa amistad que dura aún después de la muerte»).

52. Un apurado repaso de este tópico en la literatura y la emblemática puede verse en Egido Martínez, 1982: II, 213-232.

IMAGO, NÚM. 10, 2018, 7-52 
de la casa observan la escena, a través de una estrecha ranura, las personificaciones del Temor y el Deseo, pasiones que quedan así desterradas de la apacible convivencia de la pareja [fig. 15]. En el anónimo comentario de la versión castellana citada puede leerse:

«Aquí donde reyna la sobriedad, y la abstinencia, tiene su morada la quietud y el reposo, como se conoze en los hermosos y apazibles rostros destos dos Esposos, que contentándose con su tenue sustento, viven más dichosos que todos los Hombres".

Pero estas muestras de concierto conyugal son apenas un espejismo en el conjunto de la literatura emblemática. Debemos retomar ahora el hilo de la vertiente más misógina del género, y comprobar el modo en que varios de sus más representativos cultivadores inciden de forma bastante descarnada en los diferentes defectos que, a modo

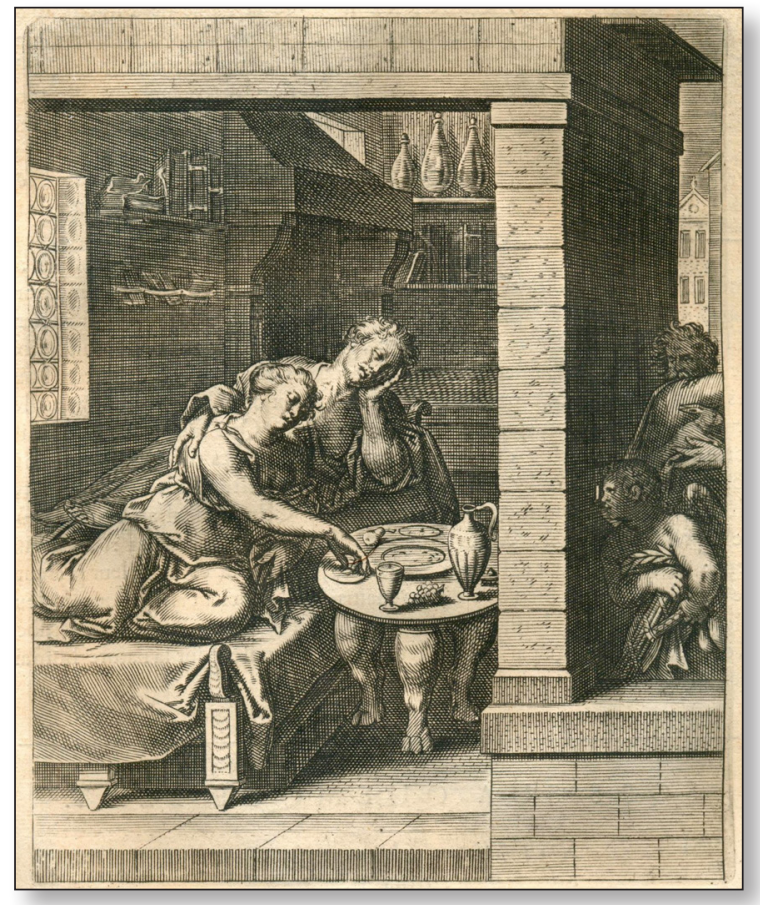

Fig. 15. Otto van Veen, Theatro moral de la vida humana, Amberes, 1701. Emb. 32. de tópicos o lugares comunes, se atribuyen a la mujer casada para tormento y escarnio de su paciente marido. Ya la profesora Escalera Pérez (2000: 771 y ss) ${ }^{53}$ reunió y analizó en su trabajo citado muchos de estos símbolos abiertamente críticos con las supuestas muestras de "femenil flaqueza», algunos de los cuales revisaremos de forma breve en las siguientes líneas.

La lista de hábitos femeninos «viciados» que serán blanco de las severas recriminaciones de los emblemistas no hace más que insistir en cuestiones ya puestas de relieve por parte de moralistas y teólogos:

a) En unos casos se considera que las mujeres son «bravas» y de mal carácter, recurriéndose para ello a la historia de Sócrates y su esposa Jantipa, tal y como muestra la imagen de uno de los grabados emblemáticos del Theatro moral de Otto van Veen [fig. 16]; de acuerdo con este relato, la mujer del filósofo, irritada por la inmutable impasibilidad de su marido ante cualquier contratiempo, llegó a arrojar una jarra de agua sobre su cabeza sin conseguir suscitar en su ánimo reacción alguna. Así nos describe el lance el anónimo comentarista del emblema:

«Ésta [Jantipa] pues, después de haver reñido largo tiempo sin razón, como lo hazía muy de ordinario. Viendo que sólo respondía Sócrates: a ti te toca el hablar mal, y a mí el oyr bien; ofendida del demasiado sufrimiento del Marido, le echó un jarro de agua a cuestas. Y el Sabio (sin alterarse) dixo con gran sossiego: No dudava yo que después de los truenos

53. A este artículo me remito para completar la información sobre las cuestiones aquí planteadas. Vid. igualmente sobre este tópico Agudo Romeo (2004: 110-111; 2008a: 2783-2784) 


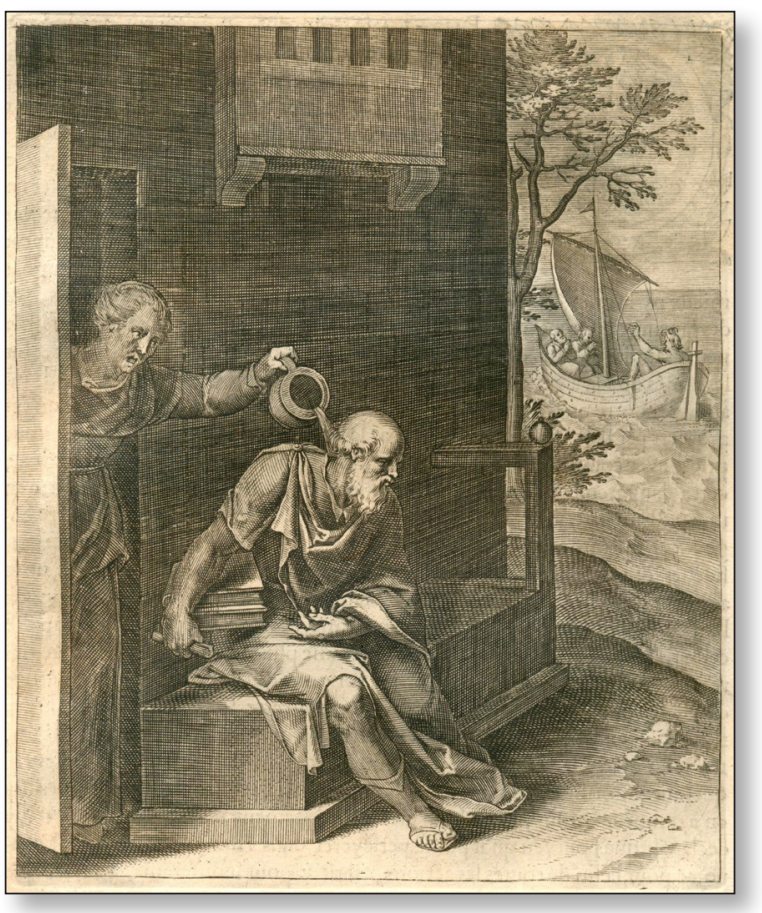

Fig. 16. Otto van Veen, Theatro moral de la vida humana, Amberes, 1701. Emb. 72. seguiría la lluvia. El día de hoy se hallan muchas Xantipes, pero muy pocos Sócrates» (Veen, 1701: emb. 72, 144-145). ${ }^{54}$

De donde se deduce que una de las principales cualidades del hombre sabio es la paciencia, valorada como "confusión de los vicios» y «reina de las virtudes", ya que con ella puede vencerse toda adversidad, incluyendo los repentinos arrebatos de la esposa, pues «la piedra de toque de la suma Paciencia, es una mala Muger». ${ }^{55} \mathrm{Se}-$ bastián de Covarrubias compara a la hembra con la planta de la albahaca, la cual, según la tradición popular, una vez que es aspirado su fuerte aroma, puede engendrar escorpiones en el cerebro; recomienda entonces que el marido trate a su mujer con «blandura y buen término [...], porque irritándola, no se convierta en escorpión, o víbora" (Covarrubias, 1610: I, fols. $53 \mathrm{r}$ y v).${ }^{56}$ Esta irascibilidad connatural puede devenir demencia cuando se in-

terponen los celos o el deseo de venganza: en otra imagen emblemática de Covarrubias [fig. 17] aparece una mujer con sus cabellos desordenados al viento y sus vestiduras desgarradas, que atraviesa con una espada a sus hijos en tanto al fondo se distingue un edificio en llamas y un carro con dos caballos alados, recordándonos, tal como nos advierte la historia de la maga Medea, ${ }^{57}$ lo extremadamente peligrosa que puede tornarse una mujer enamorada cuando se siente defraudada o engañada, pues «con ningún género de vengança le parece quedar satisfecha" (Covarrubias, 1610: III, emb. 80)..$^{58}$

54. Victrix malorum patientia ( LLa paciencia vence los males»).

55. Ya Juan Justiniano, en su traducción castellana de la Instrucción de la mujer cristiana de Vives, señala que algunas mujeres son "ásperas y mandonas», y que "por cualquier ocasión, por liviana que sea, se dejan sin freno arrebatar de la ira, y con aquel ímpetu y aceleramiento desgobernado corren a malas palabras y villanías contra sus maridos, tal que muchas veces la cosa va a parar en grandes odios y muertes». La cita procede de Vigil, $1990: 100$. 56. Emblema 53: "Tocada, y no ahaxada». Vid. Agudo Romeo, 2011 : 112.

57. Hija del rey de Cólquide y nieta de Circe, la sacerdotisa Medea se convirtió en prototipo de la hechicera en la literatura helenística y romana; enamorada perdidamente de Jasón, casó con él después de ayudarle a apropiarse del vellocino de oro en el célebre relato de los Argonautas, traicionando de este modo a su padre y su familia. Ambos tuvieron dos hijos de su matrimonio, pero, ferozmente resentida ante el propósito de Creonte, rey de Corinto, de casar a su hija con el héroe Jasón, Medea asesinó a ésta, a su padre y dio muerte también a sus propios hijos, incendiando el palacio real, y huyendo a continuación a Atenas en un carro de caballos alados, elementos que figuran al fondo de la imagen emblemática. Vid. al respecto Grimal, 1989: 336-338, s. v. "Medea".

58. Notumque furens quid foemina possit ( «Sepa de que es capaz una mujer furiosa»), fols. 280r y v. Señala Covarrubias en el epigrama: "No ay furor que se iguale al de la hembra / Si está irritada con la rabia y Zelos, / Marido y padre mata, y aun desmiembra / Y en mil pieças divide sus hijuelos». Vid. Martínez Cabezón, 2011: 477-79; Agudo Romeo, 2011: 112 .

IMAGO, NÚM. 10, 2018, 7-52 
b) En cuanto a la curiosidad malsana de las hembras, Juan de Horozco trae a colación el caso de Pandora, ${ }^{59}$ que aparece en el grabado de uno de sus emblemas abriendo la vasija de la que escapan pequeñas figuras de ángeles -los bienes- y demonios -los males-, para testimoniar la escasa confianza que nos deben inspirar sus promesas de discreción (Horozco, 1603/1604: II, 75r). ${ }^{60}$

c) Para predicar sobre su inclinación al derroche, Alciato recurre al ejemplo de Ocno, mítico fabricante de sogas, que trabaja afanosamente trenzando una de sus cuerdas, ignorante de que una burra la va devorando a medida que aquélla crece; simboliza con ello a las mujeres que consumen en ropa y adornos superfluos todo lo que el marido obtiene con gran esfuerzo (Sebastián López, 1985: 125-126). ${ }^{61}$

d) No debemos olvidar las frecuentes referencias a su presunción y coquetería: una culebra que muda su vieja piel al deslizar el cuerpo por el estrecho hueco entre dos piedras [fig. 18] nos recuerda, según Sebastián de Covarrubias, los desmedidos desvelos y sacrificios, siempre vanos, que dedican las mujeres a la preservación de su hermosura (Covarrubias, 1610: II, fols. 193r y v). ${ }^{62}$ De aquí a la reflexión sobre

59. Primera mujer según Hesíodo -Teog., 571 y ss.-, fue el regalo que todos los dioses hicieron a los hombres para su castigo; una vez llegada a la tierra, arrastrada por su curiosidad, abrió una jarra que contenía todos los males, permitiendo que se esparcieran entre el género humano. Sólo la Esperanza, que permanecía en el fondo de la vasija, no pudo escapar, pues Pandora consiguió cerrarla antes (Grimal, 1989: 405, s. v. «Pandora»).

60. Emblema 38: (sin lema). Horozco comenta al respecto (1603/1604: II, 76r): «En que se muestra [con el ejemplo de Pandora] la condición de las mugeres, y lo poco que se puede fiar de ellas, de que dan testimonio por sí las más cada día, sin tener necessidad de prueva [...] [Pandora] se dexó vencer de la curiosidad y del desseo de saber, con que sabemos fue engañada la verdadera muger primero [...]».

61. Emblema 91 (ed. 1608): Ocni effigies, de iis qui meretricibus donant, quod in bonos usus verti debeat ("Imagen de Ocno, o de los que dan a las rameras lo que debiera emplearse en mejores usos»). El propio Alciato señala «La mujer, animal flojo, arrebata al marido condescendiente las ganancias acumuladas, y las derrocha en sus adornos». El episodio de Ocno, que la literatura clásica sitúa en los Infiernos, devino metáfora, según Pierre Grimal (1989: 386, s. v. «Ocno»), del hombre muy trabajador, pero casado con una mujer muy derrochadora, tópico recogido por los humanistas del s. XVI (vid. Valeriano, 1567: XII, 90r).

62. Emblema 93: "Esto y más por remozarme». "Las diligencias que una muger entrada en años -indica el autor-, haze para detenerlos, y disimularlos, son innumerables y exquisitas, empero por más que haga, no puede detener el tiempo, ni disimular la edad, aunque los afeytes y las galas, procuren entretenerla». Tal y como observó la profesora Escalera Pérez (2000: 788-790), Covarrubias dedicó otros dos emblemas a los afanes y desengaños 


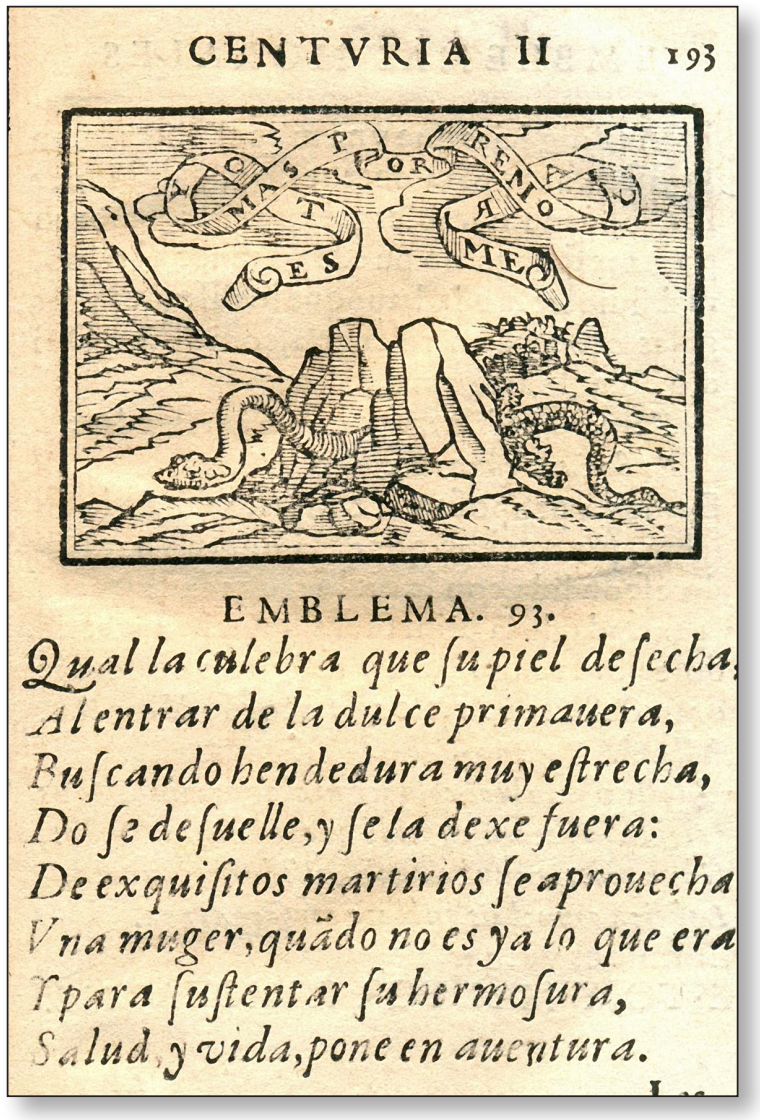

Fig. 18. Sebastián de Covarrubias, Emblemas morales, Madrid, 1610. Cent. II, emb. 93. el concepto de la vanitas -consideración consciente de nuestra finitud y de la futilidad de las glorias mundanas respecto a las venturas celestiales-, sempiterno tópico de la mentalidad barroca, hay sólo un paso: el propio Covarrubias representa sobre un podio una cabeza bifronte, con un rostro de doncella y, como opuesto, el de una calavera descarnada, para sugerir que la mujer sería más discreta y humilde si "Ver pudiesse, al espejo la figura, / En que ha de convertirse su belleza» (Covarrubias, 1610: II, fols. 193r y v).$^{63}$ A la idea anterior se encuentra íntimamente unida la del desengaño ante una realidad de apariencia siempre confusa: en un tercer emblema del mismo autor se compara a las muchachas vanidosas con aves de gran plumaje, pues, una vez desprovistas de su multicolor ornamento, se quedan en muy poca cosa (Covarrubias, 1610: III, fols. $272 \mathrm{r}$ y v) ${ }^{64}$

e) También encontramos alguna cita sobre la extremosidad del carácter femenino. Francisco de Zárraga, en uno de sus "artículos emblemáticos», muestra una mano que arroja hacia otra una pelota, explicando que en tal juego se debe ser mesurado y calibrar bien las fuerzas para no lanzar la bola, por exceso o por defecto, lejos del alcance del contrincante; tal imagen es jeroglífico de los hombres justos cuyos beneficios «[...] ni se han de arrojar con prodigalidad, ni han de ser escasos, que parezcan miseria»; sin embargo, las mujeres, propensas a permanecer en los extremos a causa de su débil naturaleza, se encuentran incapacitadas para poder mantenerse en ese aconsejable término medio (Zárraga, 1684: 83). ${ }^{65}$

que arrastra la búsqueda de la hermosura: centuria II, emblema 3: Brevis usus in illo ( "[Es] efimera la utilidad de aquélla»), fol. 103r.; y centuria II, emblema 62: Forma mihi nocuit ( "Mi belleza fue mi ruina»), fol. 162r. Vid. Escalera Pérez, 2000: 788-790.

63. Emblema 88: Quid fuerim, quidque sim, vide "Fíjate en lo que fui y en lo que soy»).

64. Emblema 72: Pars minima est ipsa puella sui ("Su menor parte es la propia muchacha»). "Comúnmente -indica el autor- las mugeres son más pequeñas de cuerpo que los hombres; empero ellas por todas las vías que pueden se empinan y vienen a parecer mayores: aprovechándose de grandes chapines, altos copetes, y grandes verdugados: pero desnudas destos ornamentos, vienen algunas a quedar enanas, semejantes a las aves, que siendo de poquitas carnes tienen grandes plumas en alas y cola».

65. Artículo 6: Utrique consulendum ("Atienda a uno y otro [extremos]").

IMAGO, NÚM. 10, 2018, 7-52 


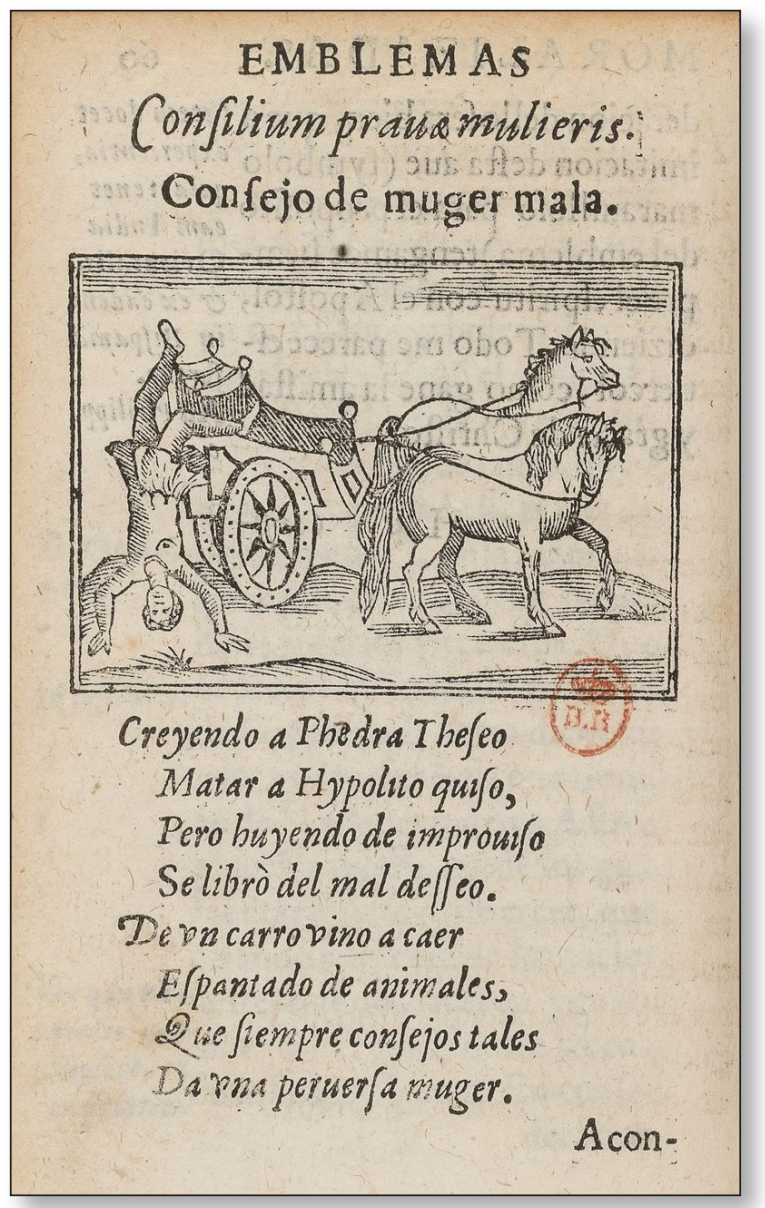

Fig. 19. Hernando de Soto, Emblemas moralizadas, Madrid, 1599. Emb. 29.
No faltan, en fin, ejemplos que aluden a las terribles consecuencias que padecen aquéllos que siguen los malos consejos de las mujeres. Juan de Horozco, por ejemplo, muestra el caso del emperador romano Heliogábalo rodeado de un senado formado exclusivamente por féminas, haciendo hincapié en lo desacertado de este criterio al pretender que «[...] governassen las que nacieron para ser governadas» (Horozco, 1603/1604: III, emb. 36). ${ }^{66}$ Del mismo modo, Hernando de Soto aconseja que se desconfíe permanentemente de los engaños y argucias de las mujeres perversas y malintencionadas: este autor nos propone para ejemplificar tal recomendación la historia de Hipólito, despeñado al caer de su carro mientras iniciaba el destierro al que le condenó su padre Teseo a causa de las falsas acusaciones de la despechada Fedra [fig. 19]. ${ }^{67}$ Aunque ya reproducido en otras ocasiones, vale la pena recordar aquí un fragmento del comentario del emblemista por su carácter paradigmático:

«Aconsejava Salomón a su hijo, y dezíale: No atiendas al engaño de la muger, porque son un panal de miel sus labios, su garganta es más blanda, y suave que el azeyte: sus fines son amargos como el absintio; su lengua es aguda como cuchillo de dos cabeças; sus pies baxan a la muerte; sus passos entran hasta dentro de los infiernos [...]. Persuadíale desta manera, como aquél que tan bien sabía los infinitos males que nacen de las mugeres, y de los consejos que dan: que harto imprudente es el que por ellos se govierna [...]: por lo qual (conforme a San Ambrosio) subjetó Dios la muger al hombre, para que no tomasse otra vez a caer en otro femenino encanto" (Soto, 1599: emb. 29). ${ }^{68}$

66. (Sin lema), fol. 172r. Añade Horozco en el comentario de este mismo emblema (fol. 172v): «Entre las demás miserias que en el tiempo de Heliogábalo vio la República Romana en daño y desautoridad suya fue la junta que este desordenado Emperador quiso ordenar de solo mugeres a quien hizo y determinó las honras y preeminencias que avían de tener edificando para ésto particular Senado [...]». Vid. Agudo Romeo, 2004: 115.

67. Hijo del rey Teseo y una amazona, fue Hipólito objeto de una intensa pasión amorosa por parte de Fedra, segunda esposa de su padre; ésta mostró su deseo al joven, pero, al verse rechazada, rasgó sus vestiduras y acusó a Hipólito de haber intentado violarla. Encolerizado, Teseo pidió a Poseidón que enviara a un monstruo marino para que asustara a los caballos del carro de su hijo cuando éste lo conducía a orillas del mar; ello provocó su muerte al ser derribado y arrastrado, con sus pies trabados en las riendas, por entre las rocas. Conocedora del mal que había causado, Fedra acabó ahorcándose (Grimal, 1989: 272-273, s. v. «Hipólito»).

68. Consilium pravae mulieris ( "Consejo de mujer mala»), fols. 60v-61v. Vid. García Arranz y Pena Sueiro, 2017: 178-180. 


\section{UNA VÍA PARA LA REHABILITACIÓN: LA "VENUS DOMÉSTICA" Y LA IMAGEN DE LA MUJER CASTA EN EMBLEMAS Y ALEGORÍAS}

Para compensar el pesado lastre de tantos y tan poco halagüeños prejuicios, la mujer que se enfrentaba al matrimonio debía tener muy presentes todos los deberes y obligaciones que para ella representaba la vida conyugal y familiar: había de asumir, en primera instancia, su debilidad y malas inclinaciones naturales para, a continuación, esforzarse por alcanzar su rehabilitación y dignificación mediante el cultivo de todas aquellas virtudes que la hacían perfecta ante Dios y su esposo (Hernández Bermejo, 1990: 61).

Un excelente ejemplo visual de este último modelo es una pintura alegórica anónima del s. XVI, conservada en el Museu Etnològic de Barcelona, titulada La donselle virtuosa [fig. 20], en la que se muestran las distintas cualidades que una mujer honesta debía alcanzar y practicar si pretendía contrarrestar sus tendencias malignas connaturales: se trata de una personificación femenina, decorosamente vestida desde el cuello hasta los pies, que se encuentra situada sobre una esfera -clara alusión al inestable equilibrio de la honestidad-, mientras eleva un libro con su mano izquierda. Aparecen a su alrededor las distintas cualidades que deben adornar su proceder, inscritas en cartelas rectangulares, algunas de ellas asociadas a elementos emblemáticos: Svbieta -sobre la cabeza de la figura, asociada a la imagen de un yugo-; Pudica y Taccita asociadas, respectivamente, a la cabeza y la boca de la dama-; Fidelis -junto a su brazo derecho-; Charitas y Casta -conectadas respectivamente al pecho y cintura-; Solicita -en cartela que cuelga de la mano derecha-; Honesta -virtud vinculada a su vientre-; y, muy cerca de sus pies, Qvieta-con el emblema del tronco de un árbol desgajado al que permanece amarrada mediante una cadena- y Humillis -con una escoba apoyada sobre el suelo- ${ }^{69}$ Prácticamente

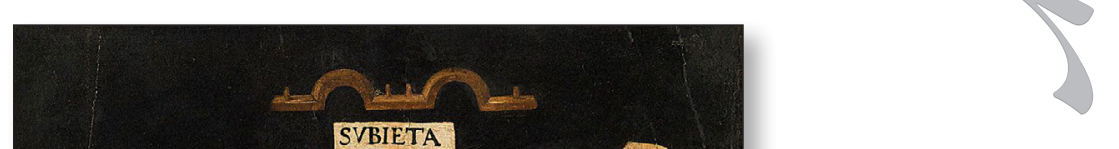

69. Como ha indicado la profesora Hernández Bermejo (1990: 61) estos llamamientos a la virtud poseían el objetivo específico de crear en la mujer una desconfianza de sí misma, de su poco valor, para que así aceptase como

IMAGO, NÚM. 10, 2018, 7-52 
todas ellas, como resulta palpable, van dirigidas a la exaltación de su templanza, fidelidad marital y servil sometimiento al cabeza de familia y al contexto hogareño.

En la literatura emblemática, la imagen más difundida de mujer virtuosa corresponde a la personificación denominada "Venus doméstica», derivada de un viejo modelo iconográfico que se remonta a la antigua Grecia. Diversos testimonios nos aseguran que, al menos desde el s. VI a. C., los helenos representaban a Venus Afrodita de pie sobre una tortuga (Cumont, 1924: 37), reptil que, en aquellos momentos, era el animal consagrado a la diosa, igual que más tarde lo serán otros como el delfín o la paloma. La representación más célebre de tal figuración fue la escultura crisoelefantina que Fidias realizó para el templo de esta divinidad en Elis o Élide, tal y como atestigua Pausanias:

«Detrás del pórtico hecho con los despojos de los de Corcira [en Elis] hay un templo de Afrodita, y un recinto sagrado al aire libre no muy lejos del templo.

A la que está en el templo la llaman Urania, que es de marfil y oro, obra de Fidias, y tiene un pie encima de una tortuga [...] El significado de la tortuga [...] lo dejo para los que quieran hacer conjeturas"..$^{70}$

Plutarco, sin embargo, no pone reparos a la hora de dilucidar el supuesto simbolismo del reptil:

«Fidias representó a la Afrodita de los Eleatas con un pie sobre una tortuga, queriendo decir que las mujeres deben cuidar la casa y guardar silencio. En verdad, conviene o bien que hable a su marido o bien a través de su marido, no molestándose si a través de una lengua extraña, produce, como el tocador de flauta, un sonido más digno". ${ }^{71}$

La tortuga aglutinaba, por tanto, un doble mensaje simbólico. Nos recuerda, por un lado, que la función de la mujer consiste en permanecer y trabajar en el ámbito doméstico -de todos es sabido que las tortugas no salen de su «casa»: la «llevan» consigo a cuestas-, ${ }^{72}$ conforme al conocido proverbio castellano «La mujer honrada, la pierna quebrada y en casa»; ${ }^{73}$

única alternativa para superar su baja condición la imitación del ideal femenino materializado en la imagen de la Virgen María, y en el ejemplo que ésta propone, pues con su victoria sobre la serpiente sometió al Pecado Original cometido por Eva.

70. Paus. VI, 25, 1 (Pausanias, 1994: 370). Como ha indicado M. Antonietta De Angelis (1984: 315), la proyección iconográfica de esta Venus fidíaca es bastante rara: aparte de los emblemas que mencionaremos a continuación, existe una escultura en el Museo del Prado de Madrid, copia de un original clásico, que muestra a una Venus en el baño apoyando un pie sobre una tortuga; se conserva también un boceto del s. XVI atribuido a Giampietrino, conservado en la Gallería dell'Accademia de Venecia, tal vez su única reproducción artística conservada del Renacimiento.

71. Coni. praec. 32; Mor. 142D (Plutarco, 1986: 193). En otros pasajes de la misma obra, el autor recomienda, tal y como se hace en Egipto, que se arrebaten a las mujeres «el calzado dorado, las pulseras, las ajorcas, los vestidos de púrpura y las perlas» para obligarlas así a permanecer en casa (Coni. praec. 30, 124C -Plutarco, 1986: 192-), y recomienda que la mujer sea parca y prudente en su discurso ante personas ajenas, "ya que en la palabra se descubren los sentimientos, caracteres y disposiciones de lo que habla» (Coni. praec. 31, 124C -Plutarco, 1986: 192-193-). Vid. igualmente Plutarco, Is. 75, Mor. 381E, cita cuyo texto reproducimos más adelante.

72. El empleo del reptil como símbolo del recato que ha de mantener la mujer casada, dado que este animal «porta con él la casa" y es mudo, fue refrendado por destacados humanistas del s. XVI (Valeriano, 1567: XXVIII, 200r, De Testudine: Virginum custodia); también Erasmo de Rotterdam, Adagiorum Opus, Chil. IV, Cent. I, XCVII: Mulierem ornat silemtium).

73. Otros refranes hispanos tradicionales hicieron referencia, sin ambages, al modo en que el pueblo resumía las celosas normas con que se cifraron los intentos de regular la reclusión de la mujer española. Mencionemos, por ejemplo, "A la mujer y a la oveja temprano la encierra», "A la mujer romera quebralla la pierna", "La mujer a la mesa sujeta», "La mujer honesta en la casa y no en su fiesta», "Mujer y la gallina, caserina", "La doncella y el azor, las espaldas hacia el sol», «La moza y el fraile mal parecen en la calle»... (Luján, 1988: 67). 
incide, por otra parte, en la conveniencia de que la fémina no sea lenguaraz e imite también en este aspecto al reptil, animal que, de acuerdo con la información proporcionada por naturalistas coetáneos como Plinio, ${ }^{74}$ carece de lengua y no puede por tanto emitir sonido alguno (Tervarent, 2002: 494, s. v. "tortuga»). Tales consideraciones de Plutarco sobre los modos de comportamiento más recomendables para el género femenino, muy comunes, por lo demás, en una ética clásica volcada en la plena dedicación al marido, fueron adoptadas de forma literal -ya lo vimos- por diversos humanistas y escritores del Renacimiento, incluyendo entre ellos al propio Andrea Alciato. El milanés, a partir de la primera edición de su Emblematum liber, dedica un emblema a esta cuestión [fig. 21], cuyo lema-Mulieris famam, non formam vulgatam esse oportere, es decir, "Conviene que se divulgue la buena fama de una mujer, no su belleza»- procede de un verso de Eurípides destinado a premiar la belleza interior de la fémina; ${ }^{75}$ en el epigrama, propuesto en forma de diálogo, podemos leer:

«-Venus nutricia, ¿qué imagen es ésa? ¿Qué significa la tortuga que oprimes con tu suave pie, Diosa?

- Así me figuró Fidias, y con esta efigie

mía ordenó que se simbolizara el sexo femenino. Y puso bajo mis pies este signo para indicar que conviene que las muchachas permanezcan en casa y sean discretas» (Sebastián López, 1985: $239) \cdot{ }^{76}$

Pero mucho más rotundos aún que el propio emblema de Alciato, son los textos incluidos en las declaraciones o comentarios que otros autores -especialmente en el s. XVII- escribieron sobre el mismo asunto, haciéndose eco de la auténtica obsesión que en la España barroca existió por el adulterio femenino. ${ }^{77}$ El extremeño Diego López, por ejemplo, indica:

74. Nat. hist. XI, 180: "La tortuga marina no tiene lengua ni dientes».

75. De acuerdo con el propio Alciato en sus De verborum significatione (1572: lex XLVI, 273).

76. Emblema 195 (ed. 1608); la trad. es de Pilar Pedraza. Vid. también sobre este asunto Agudo Romeo, 2008a: 2784-2785.

77. Como indica Mariló Vigil (1994: 139 y ss), el marido tenía derecho al uso exclusivo del cuerpo de su mujer, y su ejercicio sólo se podía hacer efectivo después del matrimonio; en tanto la mujer permanecía soltera, eran los miembros masculinos de su familia de origen los que actuaban como responsables de la custodia del derecho del hipotético futuro marido.

IMAGO, NÚM. 10, 2018, 7-52 
«En esta Emblema encierra Alciato una doctrina muy necesaria para las mugeres, amonestándolas que sean recogidas, y entiendan en su casa, y en el govierno de ella, y de su familia, para que su fama sea conocida, y no su hermosura, porque la muger no deve ser alabada, porque vista ropas de mucha costa, precio y valor, sino porque sea recogida, honesta, honrada, y de buenas costumbres [...]» (López, 1615: 449r).

En cuanto al simbolismo de la tortuga, apunta:

«[Una tortuga] la qual vive, y está siempre ençerrada entre las conchas, para significar que la muger deve estar recogida en casa, como la tortuga entre las conchas» (López, 1615: 448v).

Y respecto a la llave:

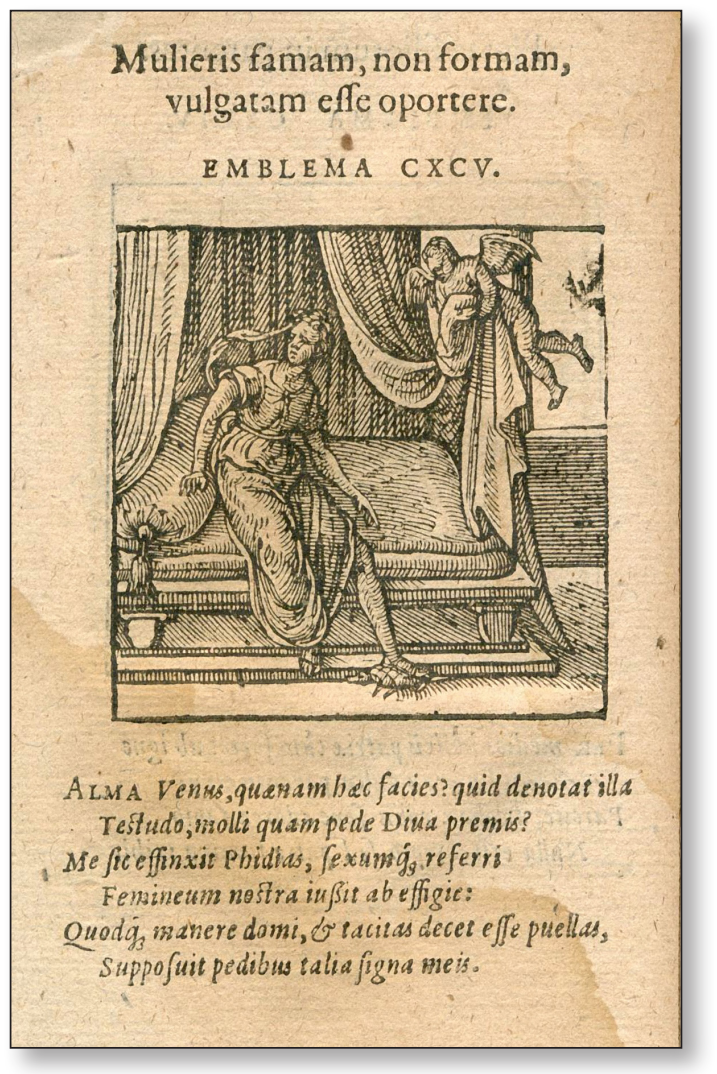

Fig. 22. Andrea Alciato, Emblemata, Amberes, 1608. Emb. 195.
"Columella [...] dize que de todo lo que se adquiere fuera de casa con el trabajo del hombre, es la llave la muger, porque ella lo ha de guardar, y conservar, y el marido ha de sufrir todas las inclemencias del cielo, trabajando en el campo, y ganando el sueldo en la guerra, y a la muger se han de entregar los negocios de casa. Esto deve hazer el marido que tiene la muger qual conviene, y al que cupo en suerte otra diferente tenga paciencia, y mire lo que mejor le conviene, que yo agora no me meto en govemar casas agenas» (López, 1615: 449v).

Tras éstas y otras indicaciones, Diego López concluye que la fama de las mujeres debe ser más celebrada que su hermosura, y que, por ello, «los mancebos que buscan muger, y quieren casarse», deben elegir a aquéllas que sean más conocidas por sus honradas cualidades que por la belleza de su apariencia física (López, 1615: 450r).

Además de los atributos indicados, en las versiones más primitivas del Emblematum liber la figura de Venus, íntegramente desnuda -a partir de mediados del s. XVI aparecerá cubierta con una casta túnica [fig. 22]- se encuentra flanqueada por sendas palomas posadas en el suelo. El ave, uno de los símbolos identificativos más habituales de la diosa desde tiempos

remotos, posee un carácter ambivalente, al connotar en unas ocasiones la lujuria -a causa de los sensuales cortejos amatorios que estas aves protagonizan-, y en otras, por el contrario, la pureza, fidelidad y castidad en el amor conyugal, ${ }^{78}$ tal y como sucede en el emblema de

78. Así lo vemos en los Hieroglyphica de Pierio Valeriano (1567: XXII: 157r-159r), donde el ave representa tanto la Castidad o la Continencia perseverante como la Lujuria, o la Caricia amatoria. 
Alciato. Joachim Camerarius, por ejemplo, representó en uno de sus símbolos a dos palomas arrastrando el carro de Venus [fig. 23], bajo el lema Sit sine labe fides ( «Sea la confianza sin mancha»), para significar a los «[...] cónyuges que viven concordes y unidos en el púdico y verdadero amor" (Camerarius, 1654b: emb. 60, fols. 62r y v; García Arranz, 2010: 573-574). Sujeta también la diosa una manzana, jeroglífico del "verdadero amor» de acuerdo con la literatura simbólica del momento (Valeriano, 1567: LIV, 395r).

Ya W. S. Heckscher (1953: 105-107) ${ }^{79}$ observó una interesante derivación que del emblema de Alciato sugirió Cesare Ripa en la figura del Pudor, propuesta como la más elevada expresión humana de las cualidades de la Virgen María, pues las acendradas virtudes domésticas de ésta, como la reserva y el silencio, tal y como se pone de manifiesto en los Evangelios, encontraron su correlato en aquella personificación de la Iconología (De Angelis, 1984: 314-316):

«Se pintará una jovencita vestida de blanco, que cubre su cabeza con un velo del color que decimos, ocultándole el rostro y llegándole casi a la cintura. ${ }^{80}$ Además, con la diestra, sostendrá un blanco lirio, hollando con sus pies una tortuga" (1625: II, 538; 1987: II, 238).

\section{De nuevo la tortuga simboliza:}

«[...] que las mujeres púdicas deberán mantenerse en el interior de sus casas, como hace este animal, que siempre se acompaña de la casa que le dio Natura [...] por cuanto el nombre y la persona de una mujer de bien para nada precisa rebasar los muros de su casa" (1625: II, 539; 1987: II, 240).

Son varios los emblemistas que retoman la figuración de Venus sobre la testudo, e inciden en los significados ya indicados (Junius, 1569: emb. 24, p. 30; emb. 50, p. 56); ${ }^{81}$ Reusner,

79. El artículo ha sido más recientemente incluido en Verheyen, Egon (Ed.), 1994: 97-109

80. El velo, explica el propio Ripa, indica que la mujer púdica «[...] debe ocultar ante los ojos ajenos la visión de la belleza de su persona, evitando con ello la ocasión de manchar el pudor con su mirada»; añade a continuación diversos testimonios clásicos y cristianos en los que se recomienda el uso del velo, tanto para salir a la calle como para acudir a los lugares sagrados (1625: II, 539; 1987: II, 239-240).

81. Los motes respectivos son Virginem pudicitiae, matronam Domus satagere ( Preocúpese la doncella de su pureza y la matrona de su casa») y Uxoriae virtutes ( "Las virtudes de la esposa»); vid. Antón Martínez, 2008: 828-830; Antón Martínez y Espigares Pinilla, 2013: 219-221; 319-320. Beatriz Antón (2008: 826-828) analiza otro emblema de Junius de interés para nuestro propósito: se trata del emblema 12, Uxoriae dotes ( Los dones de la mujer casada»), donde se representa a ésta desnuda y sentada en una silla, con los pies atados, el rostro cubierto

IMAGO, NúM. 10, 2018, 7-52 
1587: fol. Cvijb ${ }^{82}$ ). Por poner tan sólo dos ejemplos, reproduciremos aquí el comentario correspondiente al británico Geffrey Whitney:

«Esta [imagen] representa las virtudes de una esposa

Su dedo, retiene la lengua para que no corra en libertad.

El aspecto modesto, muestra su honesta vida.

La llave, declara que ella ha de mantener bajo su cuidado, y responsabilidad,

Los bienes del marido: permítele ir donde a él le plazca.

La tortuga advierte, [que ha de permanecer] en casa para gastar su tiempo» (1586: 93). ${ }^{83}$

O el del francés Guillaume de La Perriere [fig. 24]:

«En el estado en que me veis, nuestros antepasados,

A la Dama Venus antaño quisieron pintar,

Claramente se nota, que los maestros soberanos

$\mathrm{Al}$ hacerlo no quisieron engañar,

Y para alcanzar el efecto del sentido místico

Por la tortuga es necesario entender,

Que una mujer honesta no debe ir lejos,

El dedo alzado, que a hablar no se atreva,

La llave en la mano, muestra que debe

Cuidar de los bienes del marido, por prudencia» (1539, emb. 18). ${ }^{84}$

Además de la "Venus doméstica», Alciato consagró otro de sus símbolos a la necesidad de que las doncellas se encuentren protegidas de forma permanente contra los peligros del amor, pasión que puede echar a perder con enorme facilidad su honra y virginidad: el mote del emblema es, precisamente, Custodiendas virgines, esto es, "Que las vírgenes han de estar guardadas». Elige para ilustrar este concepto la imagen de Palas Atenea -o Minerva, en su versión latina-, armada con los atributos habituales y acompañada de un amenazante

pudorosamente con velo, acompañada de Cupido, al que abraza, tres manzanas de oro y dos palomas consagradas a la diosa, según el emblemista, por su pureza y seductoras caricias.

82. Custos domus uxor («El guardián del ama de casa»)

83. Uxoriae virtutes. La trad. es nuestra.

84. La trad. es de Isabelle Moreels.

IMAGO, NÚM. I0 20I8, 7-52 


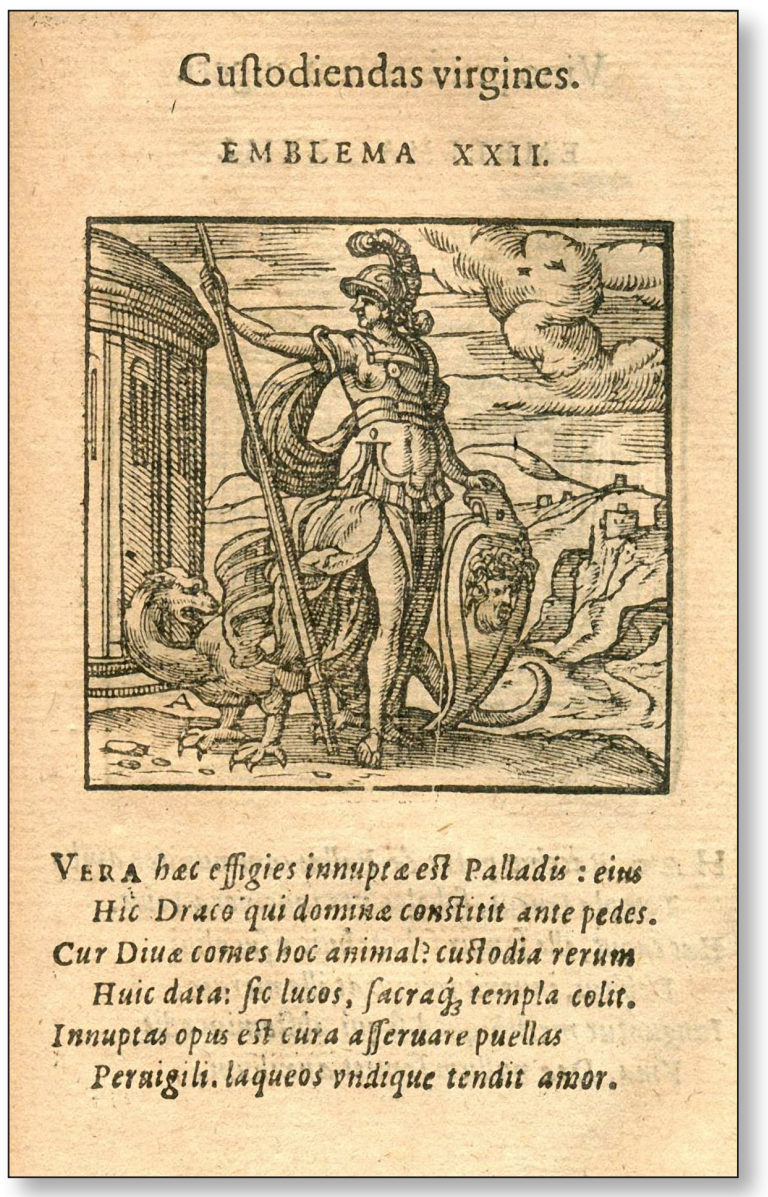

Fig. 25. Andrea Alciato, Emblemata, Amberes, 1608. Emb. 22. dragón que ruge a sus pies [fig. 25]. El sentido de esta personificación fue clarificado con los siguientes versos:

«Esta es la vera efigie de la virgen Palas, y suya es la sierpe que se halla ante sus pies.

- ¿Por qué este animal es compañero de la diosa?

- Lo tiene por custodio: guarda los bosques sagrados y los sagrados templos.

Es preciso guardar atentamente a las chicas solteras, pues el amor tiende sus lazos por doquier» (Sebastián López, 1985: 54). ${ }^{85}$

De nuevo se trata de una alegoría procedente de los textos de Pausanias $y$, sobre todo, Plutarco, quienes describen de forma muy sucinta otra estatua atribuida a la mano de Fidias en la que se representa a Atenea armada y con un dragón a sus pies; el segundo autor citado vincula simbólicamente, además, esta escultura con la de Venus asociada a la tortuga:

«A la estatua de Atenea le colocó Fidias la serpiente, y a la de Afrodita en Élide la tortuga, queriendo significar que las doncellas necesitan protección, y que para las mujeres casadas es conveniente la vida en casa $\mathrm{y}$ el silencio». ${ }^{86}$

La figura de la diosa Atenea, caracterizada con los habituales yelmo empenachado, coraza, lanza y escudo con la cabeza de Gorgona inscrita, se asoció con frecuencia al concepto de "Sabiduría» en la literatura simbólica moderna. Cesare Ripa, por ejemplo, así lo entiende al considerar a esta divinidad «con mucho la más perfecta y no pudiendo errar ni equivocarse en ninguna cosa de cuantas comportan las potencias del hombre». Se encuentra armada con asta y armadura para "resistir con gran firmeza a las fuerzas exteriores, pues el hombre, fortificado en sí mismo, puede acudir y auxiliar a los más débiles e impotentes». El escudo con la cabeza de Medusa indica

85. Emblema 22 (ed. 1608); la trad. es de Pilar Pedraza. Hadrianus Junius confrontó en uno de sus emblemas (1565: emb. 24, p. 30: Virginem pudicitiae, matronam domus satagere - Preocúpese la doncella de su pureza y la matrona de su casa»-) las figuras de Venus sobre la tortuga y de Palas Atenea como símbolos respectivos del pudor de las vírgenes y del recato de las matronas. Venus lleva una guirnalda de rosas y mirto sobre la cabeza, sustenta una paloma y tres manzanas de oro en sus manos (Junius, 2013: 219-221).

86. Plutarco, Is. 75, Mor. 381E (Plutarco, 1987: 118). En otro lugar de la misma obra -Is. 71, 379D- Plutarco señala: «Pues los Griegos [en relación con el culto rendido a los animales por los egipcios] se expresan correctamente en estos temas, y creen que la paloma es el animal consagrado a Afrodita, la serpiente a Atenea [...]" (Plutarco, 1987: 114). Vid. Agudo Romeo, 2011 : 107.

IMAGO, NÚM. 10, 2018, 7-52 
que «el Sabio debe apartar de su persona todos sus hábitos y costumbres perniciosas, y al mismo tiempo, enseñándolos y mostrándolos a los ignorantes, lograr que los rehúyan y se enmienden de sus faltas" (1625: III, 582; 1987: II, 281-282). ${ }^{87}$ Con estas indicaciones Ripa no hace sino ratificar las propiedades que ya los antiguos griegos atribuyeron a Atenea: considerada como diosa de la razón y la actividad inteligente, preside las artes, la literatura, la filosofía y diversas prácticas artesanales; ello explica que su efigie fuera venerada como amiga de la paz y patrona/protectora de diversas ciudades (Grimal, 1989: 60, s. v. «Atenea»). Pero, al mismo tiempo, Palas -o Minerva- fue considerada diosa de la Virginidad pues, a pesar de su atractivo porte -alta, de rasgos serenos, más majestuosa que bella-, permaneció doncella y se resistió sistemáticamente a los requerimientos amorosos de otros dioses.

En cuanto a la serpiente alada, o dragón, aparece en distintos relatos mitológicos como símbolo de la Vigilancia al desempeñar la misión de guardar casas, santuarios o templos: recordemos los pasajes en los que custodia el precioso Jardín de las Hespérides o la fuente Castalia. Además, su familiaridad con Palas -denominada por Homero la de los «ojos glaucos», «celestes», alusión a su aguda vista- permitió que el reptil compartiera con la diosa su naturaleza clarividente (Valeriano, 1567: XV, 111v-112r) ${ }^{88}$ En conclusión, la sabiduría de la diosa y el carácter vigilante del fabuloso animal constituyen la más eficaz protección para las vírgenes contra los imprevisibles lazos del amor, «[...] porque assí -señala Diego López (1615: 79v)- se deve armar la donzella de buenas costumbres y de buenos consejos, y deve ser muy prudente ${ }^{89}$ para guardarse».

Además de la imagen de Palas Atenea, existen otros modelos más «contrarreformistas» de la necesidad de preservar intacta la honestidad de las jóvenes doncellas. Uno de ellos fue el propuesto por Francisco de Villava, con el lema Inmota movebo - «Moveré las cosas fijas»-, en el que se nos ejemplifica por medio de una curiosa imagen [fig. 26] cuál debe ser el comportamiento de una muchacha virgen, en especial si se trata de una joven de hermoso aspecto: ha de actuar ésta como un rígido soporte de mármol -es por ello que la pictura del emblema muestra una cariátide o estípite arquitectónico cuya parte superior presenta rasgos femeninos-, que soporte con frialdad y entereza todos aquellos intentos de mancillar su integridad:

«De la que dizen ser como una imagen

Guarde bien de su honor la fortaleza,

Pues no an de faltar locos que trabajen

Por echar un borrón en su pureza.

Para este efecto, porque no la ultragen

Ya que es tan propria imagen en belleza,

Tan firme esté y entera

Que sea de mármol a quien es de cera» (1613: I, emp. 47). ${ }^{90}$

87. También Pierio Valeriano asocia esta diosa -ya sea Palas o Minerva- a la idea de Sabiduría, tanto al hablar de ella (1567: XXXVII, 271r), como de sus armas: el escudo (1567: XLII, 313r) o la lanza (1567: XV, 116r; XLII, 310r$310 v)$, que representa «la fuerza de la sabiduría» o «la prontitud del ingenio».

88. De serpente: Rex tutelaris.

89. La serpiente fue también atributo de la Prudencia, pues, según Cesare Ripa (1625: 538; 1987: II, 233), cuando el reptil es atacado, "[...] opone todas las fuerzas de su cuerpo al ataque que recibe, irguiendo la cabeza y amagando con ella mientras se envuelve en sus anillos», comportamiento acorde con la sentencia bíblica "Sed, pues, prudentes como las serpientes, y sencillos como las palomas» $(M t 10,16)$. De igual modo, Ripa propone a la serpiente como uno de los atributos de la Vigilancia (1625: 1987: II, 715).

90. «De la donzella», fols. 107v y 108r. Vid. al respecto Escalera Pérez, 2000: 772-774; D’Onofrio, 2016: 39-40. 
Su autor explica al respecto de este emblema:

«Platón dize que no es otra cosa el amor sino un desseo de hermosura. Y assí la muger que la tiene, por maravilla dexa de llevarse los ojos y el coraçón [...] de la manera que la piedra imán, por secreta virtud, atrae el hierro, que assí el alma suele ser llevada del cuerpo de una muger [...] Y assí viene a ser tan sospechosa la hermosura, que dize Juvenal, que raras vezes se conforma con la castidad [...] Considere que es imagen, y corno tal guárdese limpia y pura para Dios, y no se manche con el lodo del pecado" (1613: I, emp. 47).

No queremos cerrar este apartado sin referir otros emblemas en los que se requiere encarecidamente la discreción y honestidad de la mujer, en especial en situaciones delicadas para la honra familiar como son las -por lo demás habituales- ausencias domiciliarias del marido. En unas ocasiones, se nos proponen casos concretos, tomados de la historia o de la ficción, que se caractericen por su alto poder ejemplificante. Hernando de Soto, por ejemplo, nos expone así la historia de Laocón y la casta Marcela:

«Estando Laocón ausente,

Marcela, su muger casta,

Dél pintó una sombra vasta,

Para tenerle presente.

Era de mil perseguida,

Procurando enternecerla,

Mas no pudieron vencerla

De la sombra detenida.

Finalmente fue la guarda

De su lealtad secreta,

Que la castidad perfecta

Ella a sí mesma se guarda».

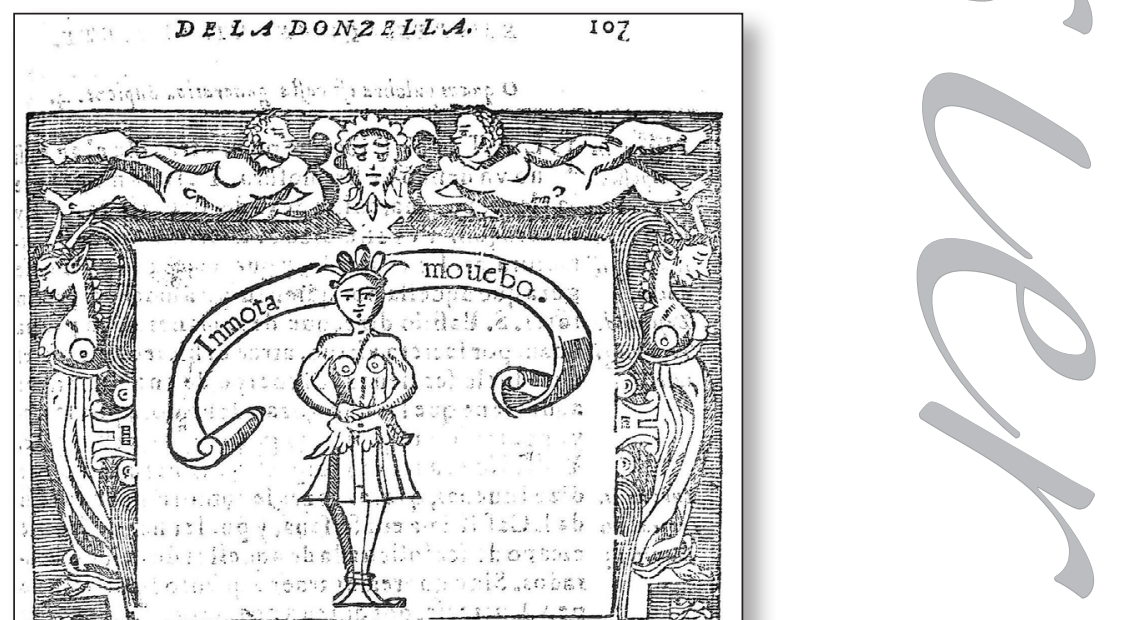

El mismo Soto se deshace en halagos sobre la virtud de la Pureza, y el merecido reconocimiento que aguarda a la mujer honesta: 
«La verdadera castidad es joya de tanto precio y valor, que le obligó a dezir a san Agustín, que era la misma virtud: porque no se ha de llamar a uno casto, que solamente lo fuere en el apetito sensual, sino en todas las demás cosas [...] Es en efecto la castidad virtud tan excelente, que premia no menos que con fama eterna" (1599: emb. 53). ${ }^{91}$

Y, en otras ocasiones, se recurre a imágenes más crípticas o metafóricas para incidir en el mismo asunto. De nuevo Sebastián de Covarrubias muestra en la pictura de uno de sus emblemas a una luna llena y un sol, distanciados entre sí en el cielo, brillando sobre un paisaje en el que se distingue una población [fig. 27]. Al pie de esta ilustración podemos leer:

«La fee, y la lealtad de la casada Reluce, estando ausente su marido, Quanto más escondida, y retirada, Tanto más su valor es conocido: Qual luna, que del sol siendo arredrada Su rostro os mostrará, lleno y fornido, Y no sabiendo entonces governarse, En fama y en honor, puede eclypsarse».

Por si aún no quedara suficientemente claro, Covarrubias declara así el significado de la composición:

«Gozamos de su plenitud [de la luz de la luna] quando está en la mayor distancia del Sol, la qual es propio símbolo del retraymiento de la muger casada, quando haziendo su marido ausencia, quanto más se alexa y tarda, tanto más vive recogida y recatada, mostrando en esto su valor y fidelidad" (Covarrubias, 1610: II, emb. 41). ${ }^{92}$

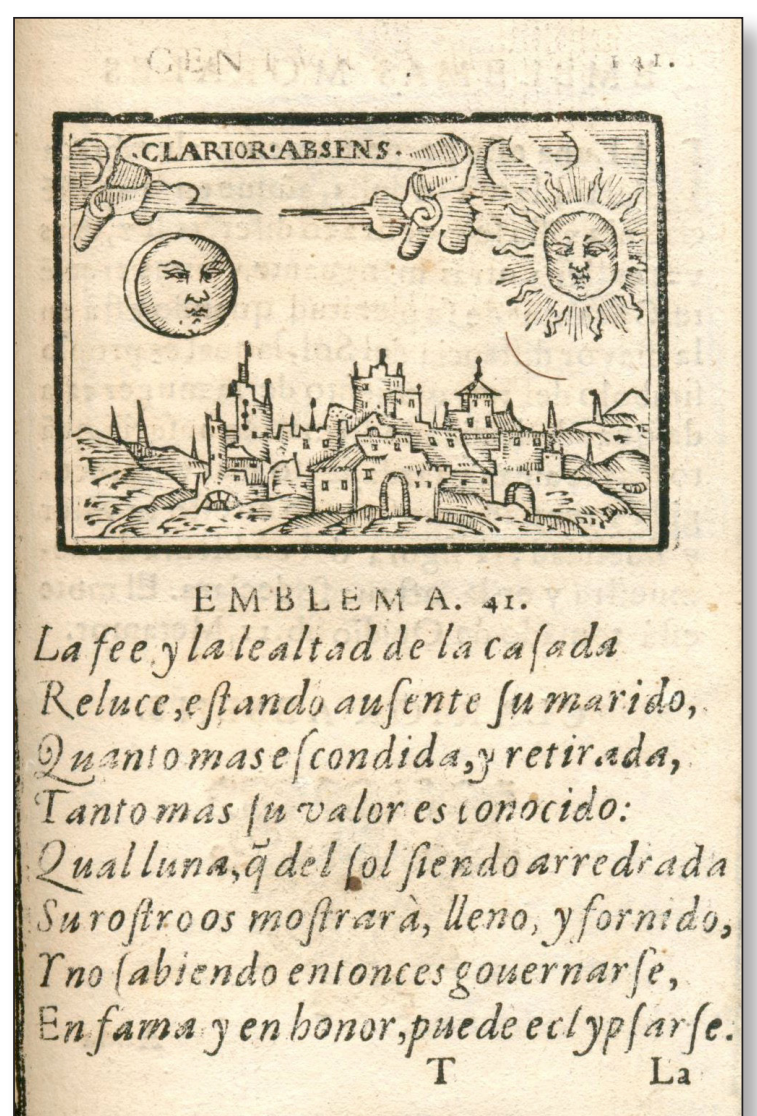

Fig. 27. Sebastián de Covarrubias, Emblemas morales, Madrid, 1610. Cent. II, emb. 41.

\section{OTROS ATRIBUTOS DE LA CASTIDAD FEMENINA}

Además de las figuras y símbolos analizados en el apartado precedente, el iconólogo Cesare Ripa propuso diversas personificaciones y variantes del concepto de «Castidad» o «Castidad matrimonial», con sus correspondientes atributos. Entre ellos se encuentran, como más sig-

91. Vera castitas ( La castidad verdadera»), fols. 112 v. y 113r. Vid. Escalera Pérez, 2000: 772-773; Agudo Romeo, 2011: 116-117; García Arranz y Pena Sueiro, 2017: 251-253.

92. Clarior absens ( "Más brillante estando ausente»), fol. 141r. Vid. Escalera Pérez, 2000: 771-772; Agudo Romeo, 2011: 113 . 
nificativos, diversos animales con cuyos comportamientos -reales o imaginarios, pero siempre entresacados de la tradición zoológica precedente- se trazan o ejemplifican los rasgos que se consideran esenciales en el comportamiento óptimo de la mujer familiar, y que nos permiten terminar de esbozar una imagen conceptual que complementa la de las series emblemáticas anteriores. Enumeraremos en las siguientes líneas algunos de los motivos zoológicos más representativos.

\section{EL UNICORNIO}

En la explicación correspondiente a la figura del Carro de la Castidad, inspirada directamente en la descripción propuesta por Francesco Petrarca en sus Triunfos, Ripa indica que esta virtud ha de representarse como una

\footnotetext{
«Hermosa mujer toda vestida de blanco, que va sobre un carro tirado por dos licomios. Con la derecha sostiene una rama de Palma y con la izquierda un escudo de cristal, en la mitad de la cual se ha de ver una columna de jaspe. A sus pies se pondrá un Cupido, atado, con las manos a la espalda, y con el arco y las flechas rotas en pedazos» (1925: I, 93; 1987: I, 180).
}

El licornio o unicornio será uno de los tópicos habituales asociados al concepto de Pureza. El Physiologus y los bestiarios medievales consideraban que este fabuloso animal, astuto y huidizo, tan sólo podía ser capturado con la inestimable colaboración de una joven doncella, en cuyos brazos se recuesta y adormece confiado; en las ilustraciones de estas obras aparece el animal representado en el regazo de la dama mientras los cazadores le lancean y dan muerte. Adquiere de este modo una interpretación cristológica, al representar esta imagen la encarnación del Salvador en el seno de la Virgen María y su ulterior sacrificio por el género humano. Este significado se transforma al trasladarse al género emblemático, donde será símbolo de la vida casta y pura; para subrayar esta lectura, en algunos emblemas continúa el animal recostado en el seno de la doncella si bien los cazadores desaparecen, sustituidos ahora por unas serpientes y otros animales ponzoñosos, encarnación de vicios y tentaciones, que huyen reptando, incapaces de enfrentarse a tan deslumbrante icono de amor casto y honesta virtud (Camerarius, 1654a: emb. 13) [fig. 28]. ${ }^{93}$

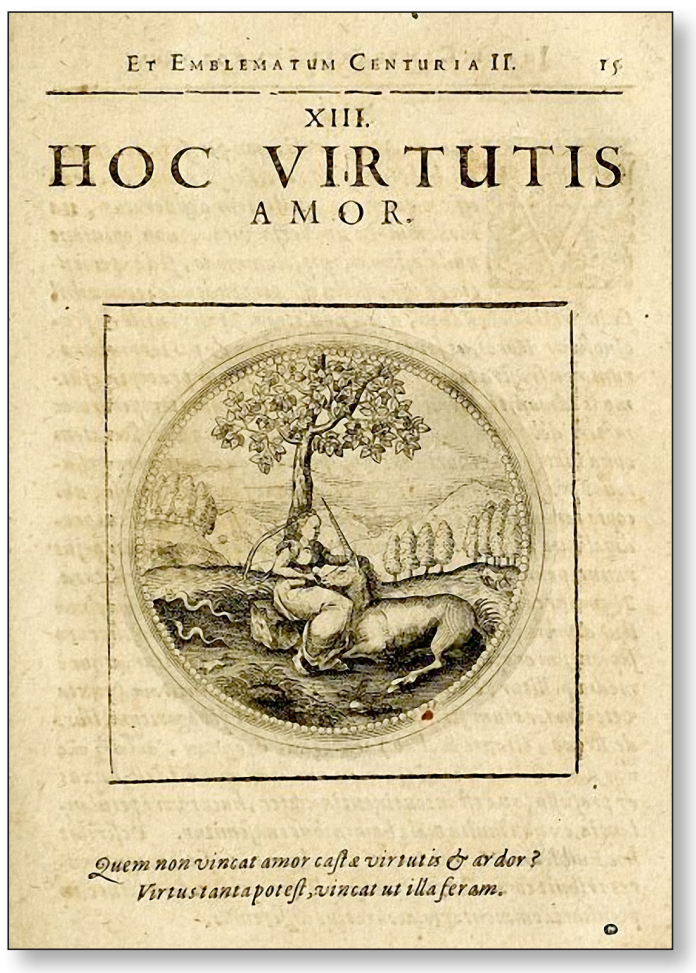

Fig. 28. Joachim Camerarius, Symbolorum et emblematum ex animalibus quadrupedus, Franckfurt am Main, 1654. Emb. 13. 
En cuanto al Cupido maniatado de la descripción de Ripa, es motivo procedente de uno de los emblemas de Alciato (Sebastián López, 1985: 146-147). ${ }^{94}$ En él puede apreciarse a Anteros -joven desnudo y alado, divinidad del amor recíproco y honesto-, que ata a un árbol a Eros -símbolo, como su madre Venus, del amor carnal, representado como el anterior, pero con aspecto más aniñado- mientras las armas de este último, carcaj, flechas y arco, se consumen entre las llamas: se indica así que el amor puro y "celestial» siempre acaba venciendo a los torpes y deshonestos deseos que infunde el arrogante hijo de Afrodita.

\title{
LA TÓRTOLA Y EL ARMIÑO
}

En su descripción de la Castidad matrimonial, el perugino Cesare Ripa escribe:

\begin{abstract}
«Mujer vestida de blanco, que lleva en la cabeza una corona de ruda. Con la diestra sostiene una rama de laurel, y una Tórtola con la siniestra [...] La Tórtola nos enseña con su ejemplo a no mancillar jamás la honra y la fe del Matrimonio, relacionándose sólo con aquella otra a la que desde un principio eligió por compañera. También se puede añadir un armiño, por el gran cuidado que tiene de no ensuciar su blancura, al igual que lo hacen aquellos que en la Castidad se mantienen» (1625: I, 97; 1987: I, 181-182).
\end{abstract}

En otra versión de la misma alegoría comenta:

«Mujer que lleva el rostro velado. Va vestida de blanco y caminando, mientras sostiene un Cetro con la derecha y con la izquierda dos Tórtolas [...] Las Tórtolas, según lo refiere Pierio Valeriano [...] son símbolo de la Castidad, por cuanto esta ave, si pierde a su compañera, no vuelve a emparejarse nunca" (1625: 97; I, 1987: I, 182).

Tal y como se sugiere en estos textos, la pareja de tórtolas constituye un atributo habitual de la alegoría del matrimonio casto y fiel. La idea tradicional de la perpetua unión de la hembra de la tórtola a un solo macho, hasta el extremo de no aceptar ningún otro compañero, aparece ya consolidada en los textos animalísticos de la Antigüedad, como la Historia de los Animales de Aristóteles. ${ }^{95}$ Tanto las palomas torcaces como las tórtolas se consideran, en consecuencia, aves de gran templanza sexual, pues forman parejas comprometidas en una especie de lazo matrimonial que las mantiene siempre unidas para así refrenar cualquier tipo de apetito ilícito. Estas connotaciones de fidelidad conyugal y abstinencia camal que latían en el comportamiento atribuido a la tórtola, favorecerán su uso como referencia modélica para las mujeres cristianas desde los más tempranos textos patrísticos. Será propuesta por tanto como símbolo de Castidad-avis pudica- y de la viudedad ejemplar, al no admitir el ave la compañía de ningún otro macho después de la muerte de su compañero.

Son frecuentes los emblemas o empresas en cuyas ilustraciones también aparecen las dos tórtolas unidas en una fiel pareja. El sienés Scipione Bargagli (1594: 192-193) ${ }^{96}$ o el médico alemán Joachim Camerarius (1564a: emb. 63, fols. 65r y v) incluyeron en sus obras

94. Emblema 110 (ed. 1608): Amor virtutis alium Cupidinen superans ("Anteros, el amor a la virtud, vence al otro Cupido»).

95. «La tórtola, y también la paloma torcaz, se mantiene vinculada siempre al mismo macho, y no admite otro. Y efectúan la incubación de los huevos ambos, tanto el macho como la hembra», HA IX, 7, 613a (Aristóteles, 1990: 494).

96. Se trata de una divisa conmemorativa del matrimonio celebrado entre la Reina Juana de Austria y el Duque florentino Francisco. 
la imagen de ambas aves posadas en el suelo, ante un paisaje campestre, situadas una junto a la otra en amorosa compañía; con el mote Fida coniunctio -o Coniunctio fida, «El matrimonio fiel»- tratan de significar "[...] o nodo marital e stretto con vera lealtà, e sincerissima fede».

También encontramos a nuestra ave como protagonista de numerosos emblemas en los que aparece solitaria y silenciosa en la rama seca de un árbol, representando a la viuda que permanece fiel a su marido muerto, cuya memoria llora durante el resto de sus días. Tal recomendación de viudedad casta ejemplificada en el ave aparece en las más tempranas referencias literarias cristianas, siguiendo fielmente las directrices de Pablo de Tarso. A través de la literatura moral medieval, el mensaje llega a los ss. XVI y XVII; es por ello que Sebastián de Covarrubias señala que, entre otras posibles interpretaciones, la imagen de la tórtola solitaria y triste, con el mote hispano "Cantando lloro», es "[...] symbolo de la biuda que, muerto su marido, passa el resto de la vida en soledad" (1610: I, emb. 62) ${ }^{97}$ [fig. 29].

En cuanto al armiño, constituye otro de los símbolos más extendidos de pureza y castidad. Esta concepción procede, además del intenso candor y limpieza de su apreciada piel, de fuentes literarias grecolatinas. Claudio Eliano indica:

«Pero, cuando [el armiño] cae en una rodera [o rodada de un camino], queda preso por una especie de traba completamente invisible, y muere». ${ }^{98}$

Ello explica que Petrarca incluyera al animal como insignia del cortejo de las mujeres que acompañan a la personificación de la Castidad, y aparecerá desde ese momento en numerosos cuadros, grabados y reversos de medallas referidos a esta virtud. ${ }^{99}$ Por idéntica razón numerosos monarcas adoptaron la imagen del armiño en medio de un círculo de barro con la letra Malo mori quam foedari ( "Prefiero morir antes que ser mancillado») como su

97. Fols. 62r y v. También Pierio Valeriano (1567: XXII, 517r y 518v) considera al ave símbolo de Castidad y de Viudedad continente.

98. De an. II, 37 (Claudio Eliano, 1989: 99). Vid. también Plinio el Viejo, Nat. hist. VIII, 227.

99. Algunas de estas obras aparecen recogidas por Tervarent (2002: 69, s. v. "armiño").

IMAGO, NÚM. 10, 2018, 7-52 


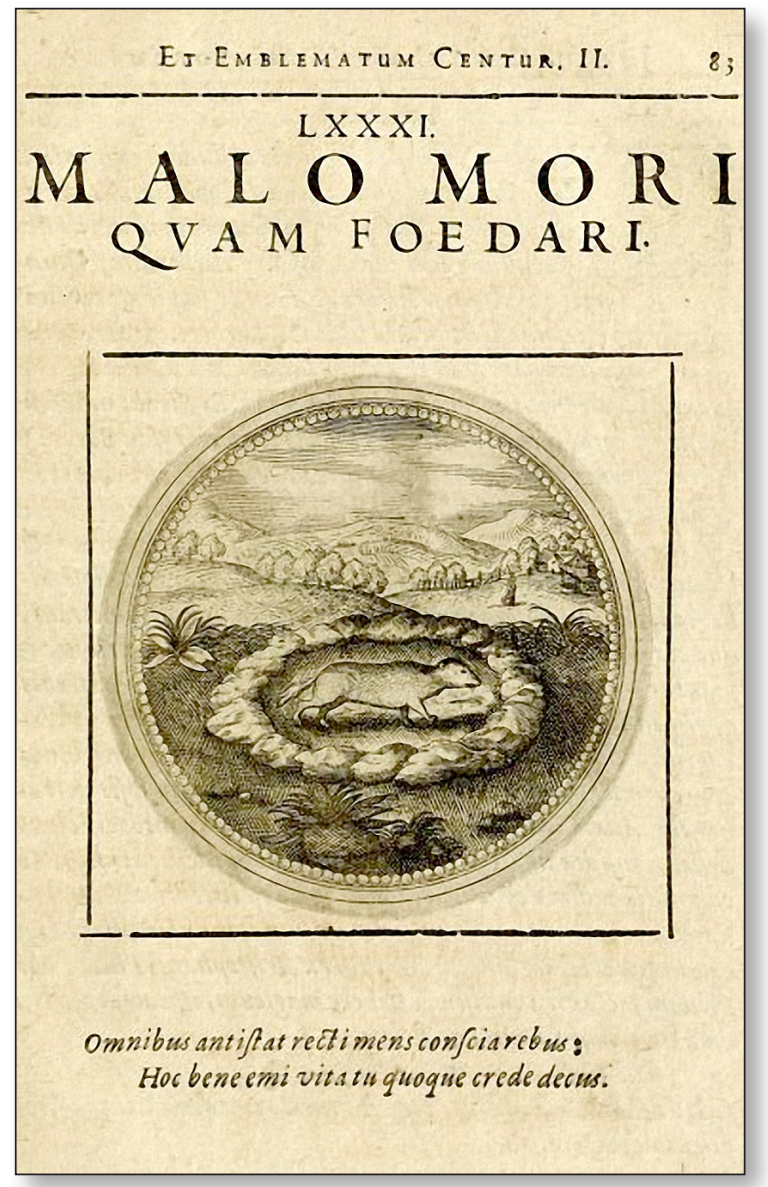

Fig. 30. Joachim Camerarius, Symbolorum et emblematum ex animalibus quadrupedus, Franckfurt am Main, 1654. Emb. 81. divisa personal: Tervarent (2002: 6869) menciona, por ejemplo, el caso de Fernando I de Nápoles, Ana de Bretaña -mujer de Luis XII- o su hija Claudia de Francia -esposa de Francisco I-. Aparte de los tratados de Ripa o Pierio Valeriano (XIII, 100r-100v), algunos emblemistas, como Paolo Giovio (1574: 36) $)^{100}$ o Joachim Camerarius (1564a: emb. 81) ${ }^{101}$ [fig. 30], recogieron este símbolo de la realeza con la significación ya indicada.

\section{EL CALAMÓN}

Andrea Alciato empleó la imagen de un calamón, ${ }^{102}$ representada en un escudo que cuelga de un árbol [fig. 31], como símbolo de Pudicitia -«Pudor»- desde las ediciones del Emblematum liber correspondientes a la traducción castellana de Daza Pinciano (Lyon, Mathias Bonhome, 1549). El humanista milanés escribe sobre este emblema:

«El calamón, si su pareja profana su morada con el adulterio, queda abatida y muere de dolor. La causa está escondida en los arcanos de la Naturaleza: sea esta ave símbolo cierto del pudor sincero" (Sebastián López, 1985: emb. 47, 83).

Tal idea fue consolidada por Alciato a partir del testimonio directo, una vez más, de naturalistas del mundo antiguo, alguno tan pintoresco como el de Claudio Eliano:

«[El calamón] es muy celoso y no pierde ojo a las hembras que andan en relaciones clandestinas con machos y si comprueba que en su casa el ama comete adulterio, se ahorca». ${ }^{103}$

También el emblemista Nicolás Reusner se refiere al calamón en los mismos términos que Alciato en uno de sus emblemas, con el mote Casta placent superis - «Los castos agradan a los dioses»-. Este autor, poniendo como ejemplo la conducta del ave, nos advierte sobre la pérdida de la razón y otras nefastas consecuencias a las que nos pueden arrastrar los amo-

100. Malo mori quam foedari ( «Mejor la muerte que el deshonor»).

101. Malo mori quam foedari, fols. $83 \mathrm{r}$ y v.

102. Se trata de un ave acuática de marisma de la familia de las Rallidae, de anatomía robusta, y largas patas, que vive en lagunas y zonas pantanosas con vegetación espesa.

103. De an. III, 42 (Claudio Eliano, 1989: 140). En De an. V, 28, el autor prenestino vuelve a insistir en el carácter extremadamente celoso del ave. 


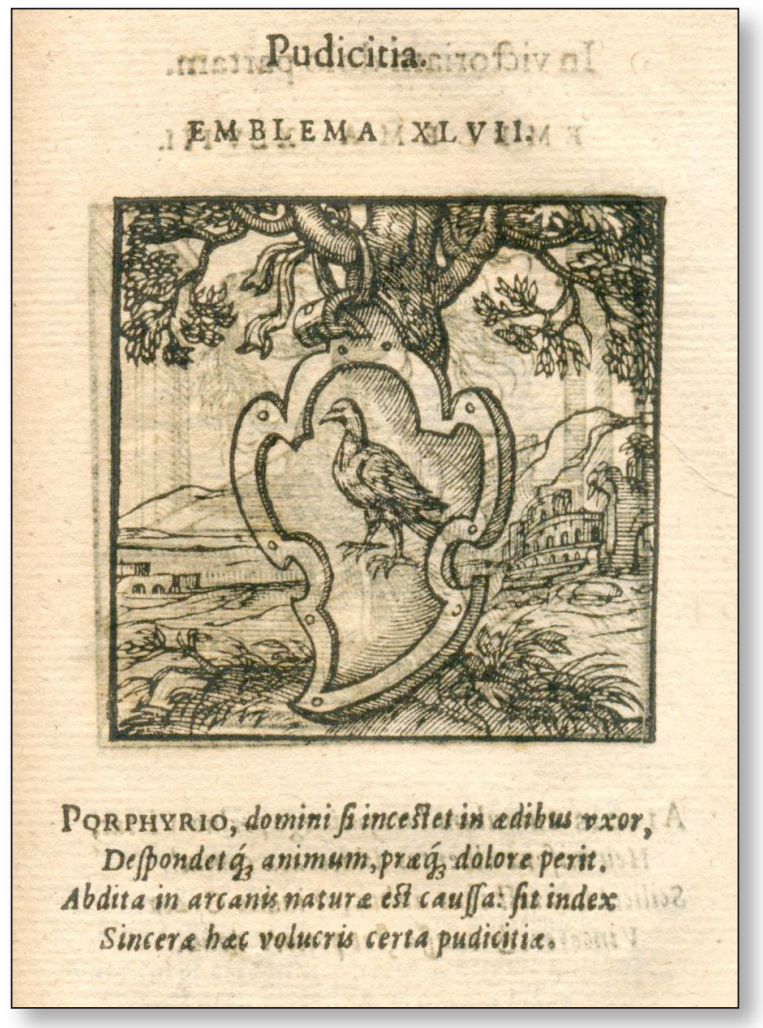

Fig. 31. Andrea Alciato, Emblemata, Amberes, 1608. Emb. 47. res furtivos, aguardando, sin embargo, incontables venturas a aquellas personas que fundamentan su existencia en una probada castidad (Reusner, 1581: emb. 5, 61-62).

\section{A MODO DE CONCLUSIÓN}

Como hemos podido constatar a lo largo de estas páginas, nada nuevo añadió la literatura simbólica ilustrada de estas centurias -género, por lo demás, de creciente conservadurismo en sus postulados- a la concepción de lo femenino instaurada y difundida desde la ideología dominante. Sin embargo, aquellas obras sí resultan altamente ilustrativas de los modos en que sus planteamientos y argumentos fueron traducidos en imágenes, recurso que suscita un mayor grado de atención que los textos, y resulta de más rápida y eficaz asimilación por parte de un público muchas veces iletrado. Además, junto al componente puramente visual, emblemas y alegorías reúnen unas propiedades que incrementan su poder sugestivo y formativo: sus grabados presentan, a través de los distintos motivos o escenas, un enigma transitorio que debe ser clarificado con ayuda del mote y las declaraciones o explicaciones; pero la resolución de este mensaje cifrado no puede llevarse a cabo sin ciertas dosis de erudición o ingenio, factor de dificultad que, una vez superado, ayuda a fijar de modo más permanente el concepto en la memoria. Se recurre, por otra parte, al alto poder ejemplificador y moralizante de episodios míticos, personajes históricos o comportamientos atribuidos a los animales que gozaban de cierto predicamento en la cultura popular del momento gracias al teatro o la poesía; a través de los emblemas o los atributos de personificaciones se van trazando, con una precisión maniquea, las virtudes que debe cultivar la mujer honesta -incluyendo la sumisión al hombre y su silenciosa reclusión hogareña-, y los comportamientos que debe desterrar como inconvenientes o pecaminosos. ${ }^{104}$

En consecuencia, este tipo de literatura ilustrada fue un instrumento más que se sumó, con su potencial visual y pedagógico, a los textos formativos y morales ya citados con el

104. Ya hace algunos años que José Antonio Maravall (1984: 199 y ss) puso de manifiesto el método pedagógico del género emblemático, consolidado durante el periodo Barroco: el empleo de ilustraciones que despiertan la curiosidad del lector, el recurso frecuente a exempla que consolidan la validez del concepto propuesto, y, por último, el factor de dificultad calculada que supone la interdependencia significativa entre grabado, lema y epigrama del emblema, todos ellos factores destinados a reforzar el mensaje del emblema, imprimirlo mejor en la memoria, e incrementar, en definitiva, su efectividad pedagógica.

IMAGO, NÚM. 10, 2018, 7-52 
objeto de encauzar las acciones y pensamientos de los súbditos -en este caso los de género femenil- de acuerdo con unos modelos familiares y unos patrones de comportamiento bien definidos durante siglos de control ideológico masculino. Parece ser que el efecto de aquella campaña mediática fue profundo y duradero: prueba de ello es la inusitada vigencia que muchos de los prejuicios vertidos en los viejos tratados morales y simbólicos siguen manteniendo en no pocos sectores de la sociedad actual. Tal situación es fruto, sin duda, de la incidencia indeleble de unas nociones educativas discriminatorias y del mantenimiento de unos usos y costumbres estrictamente tradicionalistas que se han venido imponiendo en nuestro país, de forma dogmática, hasta hace tan sólo una generación. En tanto estas pervivencias no acaben de desvanecerse, no cesarán sus consecuencias sintomáticas, a veces trágicas, que afloran casi a diario en nuestro entorno cotidiano.

\section{BIBLIOGRAFÍA}

Agudo Romeo, $M^{a}$ del M. [2004]. «La mujer en los Emblemata moralia (Agrigento, 1601) de Juan de Horozco", en S. López Poza (ed.), Florilegio de Estudios de Emblemática, Actas del VI congreso Internacional de Emblemática de The Society for Emblem studies, A Coruña, Sociedad de Cultura Valle Inclán, 109-118.

Agudo Romeo, $M^{a}$ del M. [2008a]. «Fuentes literarias en prototipos femeninos de la emblemática», en J. Ma Maestre Maestre, J. Pascual Barea y L. Charlo Brea (coords.), Humanismo y pervivencia del mundo clásico: homenaje al profesor Antonio Prieto (Literatura castellana y mundo clásico), Alcañiz/Madrid, CSIC, vol. 1, 2777-2790.

Agudo Romeo, $M^{a}$ del M. [2008b]. "La leona, símbolo de la mala mujer», en R. García Mahíques y V. ZuRiaga Senent (eds.), Imagen y cultura: la interpretación de las imágenes como Historia cultural, Valencia, Generalitat Valenciana, Universitat Internacional de Gandía/ Biblioteca Valenciana, vol. I, 129-137.

Agudo Romeo, $M^{a}$ del M. [2009]. "Animales, monstruos y plantas, símbolos de la mujer en la literatura emblemática», en $\mathrm{M}^{a} \mathrm{~T}$. Muñoz García de Iturrospe (coord.), Antiguos y modernos: presencias clásicas, de la Antigüedad al siglo XXI, Bilbao, Universidad del País Vasco, 175-216.

Agudo Romeo, Ma del M. [2011]. "Cuestiones matrimoniales en libros de emblemas», en R. Zafra Molina y J. J. Azanza López (coords.), Emblemática trascendente: hermenéutica de la imagen, iconología del texto, Pamplona, Universidad de Navarra / SEE, 103-118.

Alciato, A. [1572], De verborum significatione libri IIII, Lyon, Antonius Gryphius.

Alciato, A. [1531], Emblematum liber, Augsburgo, Heinrich Steyner.

ALCiato, A. [1608], Emblemata, Amberes, Christoph Plantin.

Anderson, B. S. y Zinnser, J. P. [1991], Historia de las mujeres: una historia propia, Barcelona, Critica (2 vols.).

Antón Martínez, B. [2008], «El binomio mujer virtuosa/ mujer perversa en los Emblemata (1565) de Adriano Junio», en C. Chaparro Gómez, J. J. García Arranz, J. Roso díaz y J. Ureña Bracero (eds.), Paisajes emblemáticos: la construcción de la imagen simbólica en Europa y América, Mérida, Editora Regional de Extremadura, 825-847.

Antón Martínez, B. [2009], "El 'apareamiento oral' (oris coitus) de las serpientes y su simbología en la literatura emblemática neolatina», Imago. Revista de Emblemática y cultura visual, 1, 99-116. 
Antón Martínez, B. y Espigares Pinilla, A. (eds.) [2013], Adriano Junio: Emblemas, Zaragoza, Libros Pórtico.

Arbiol, A. [1715], La familia regulada con doctrina de la Sagrada Escritura, y Santos Padres de la Iglesia Católica, Zaragoza, Herederos de Manuel Román.

Aristóteles [1990], Historia de los animales, ed. y trad. de J. Vara Donado, Madrid, Akal.

Astete, G. de [1603], Tratado del gobierno de la familia y estado de las viudas y doncellas, Burgos, Felipe Iunta.

Bargagli, S. [1594], Dell'imprese, Venetia, Francesco de Franceschi.

Bernat Vistarini, A. y Cull, J. T. (Eds.) [1999], Enciclopedia Akal de emblemas españoles ilustrados, Madrid, Akal.

Biblia DE JERUSALÉN [1994], Bilbao, Desclée de Brower/ Alianza Editorial.

BruneI, A. de [1665], Voyage d 'Espagne curieux, historique et politique, París, Charles de Sercy.

CAmerarius, J. [1654a], Symbolorum et emblematum ex animalibus quadrupedus, Franckfurt am Main, Johann Ammon.

CAMERARIUS, J. [1654b], Simbolorum et emblematum ex volatilibus et insectis desumtorum centuria tertia collecta, Franckfurt am Main, Johann Ammon.

Claudio Eliano [1989], Historia de los animales, ed. y trad. de J. Vara Donado, Madrid, Akal.

Covarrubias Orozco, S. de [1610], Emblemas morales de don Sebastián de Covarrubias Orozco, Madrid, Luis Sánchez (Edición facsímil, con introducción de C. Bravo-Villasante, Madrid, Fundación Universitaria Española, 1978).

Cumont, F. [1924], "L"Aphrodite à la tortue' de Doura-Europos», Monuments Piot, 27, 31 43.

De Angelis, Ma A. [1984], Gli emblemi di Andrea Alciato nella ediziones Steyner del 1531. Fonti e simbologie, Salerno, la autora.

De Vega, E. [1996], La mujer en la historia, Madrid, Anaya.

Deleito Y Piñuela, J. [1994], La mala vida en la España de Felipe IV, Madrid, Alianza.

Déonna, W. [1920], "Aphrodite sur la tortue», Revue de l'Histoire des Religions, 81, 135-144.

Díez Borque, J. Ma [1990], La vida española en el Siglo de Oro según los extranjeros, Barcelona, Ediciones del Serbal.

D'onofrio, J. [2016], «La atracción femenina: poder, peligro y ejemplo. El caso de las doncellas cervantinas», Exlibris. Revista del Departamento de Letras, 5, 33-50

Egido Martínez, A. [1982], «Variaciones sobre la vid y el olmo en la poesía de Quevedo: Amor constante más allá de la muerte», en Homenaje a Quevedo, Salamanca, tomo II, 213-232.

Escalera Pérez, R. [2000]. "Monjas, madres, doncellas y prostitutas. La mujer en la Emblemática», en V. Mínguez Cornelles (ed.), Del libro de emblemas a la ciudad simbólica. Actas del III Simposio Internacional de Emblemática Hispánica, Castellón, Universitat Jaume I/ Bancaixa, 769-791.

Escalera Pérez, R. [2001]. "La mujer en la Emblemática (s. XVI-XVII)», en M $^{a}$ T. SAuret Guerrero y A. Quiles Faz (eds.), Luchas de género en la historia a través de la imagen. Ponencias y comunicaciones, Málaga, Centro de Ediciones de la Diputación Provincial de Málaga (CEDMA), vol. 1, 700-718.

Fernández Álvarez, M. [1989], La sociedad española en el Siglo de Oro, Madrid, Gredos (2 vols.). García Arranz, J. J. [2005], "Uxoriae virtutes. La imagen de la mujer virtuosa y su contexto en la cultura simbólica de la Edad Moderna», en J. L. DE LA Montaña Conchiña e I. RodríGUEz SÁnchez (coords.), De la intimidad y el susurro al poder, Badajoz, Servicio de Publicaciones de la Excma. Diputación Provincial de Badajoz, 49-116. 
García Arranz, J. J. [2001], «The Whore of Babylon: Tradition and Iconography of an Apocaliptic Motif in the Service of Modern Religious Polemics», en P. M. Daly y J. T. Cull (eds.), In Nocte Consilium. Studies in Emblematics in Honor of Pedro F. Campa, Baden-Baden, Valentin Koerner, 153-179.

García Arranz, J. J. [2010], Symbola et emblemata avium. Las aves en los libros de emblemas y empresas europeos de los siglos XVI y XVII, A Coruña, SIELAE/ Sociedad de Cultura Valle Inclán.

García Arranz, J. J. y Pena Sueiro, N. (eds.) [2017], Hernando de Soto: Emblemas moralizadas, Palma de Mallorca, José J. de Olañeta Editor.

García Mahíques, R. (ed.) [1988], Empresas sacras de Núñez de Cepeda, Madrid, Tuero.

García Mercadal, J. (ed.) [1959], Viajes de extranjeros por España y Portugal, tomo II: siglo XVII, Madrid, Aguilar.

Giovio, P. [1574], Dialogo dell'imprese militari et amorose, Lyone, Guglielmo Rovillo.

Grimal, P. [1989], Diccionario de mitología griega y romana, Barcelona, Paidos.

GuevarA, A. de [1539], Epístolas familiares, Valladolid, Juan de Villaquirán.

Heckscher, W. S. [1953], "Aphrodite as a Nun», The Phoenix, 7, 105-107.

Hernández Bermejo, Ma Á. [1990], La familia extremeña en los tiempos modernos, Badajoz, Dpto. de Publicaciones de la Diputación de Badajoz.

Hernández Miñano, J. de D. (ed.) [2015], Emblemas morales de Sebastián de Covarrubias. Iconografía y doctrina de la Contrarreforma, Murcia, Servicio de publicaciones de la Universidad de Murcia.

Horozco Y Covarrubias, J. de [1603/1604], Emblemas morales, Çaragoça, Alonso Rodríguez. Horozco Y Covarrubias, J. de [1601], Emblemata moralia, Agrigento, [s. n.].

Járava Del Castillo, D. [1675], Estado del matrimonio. Apariencias de sus placeres, ebidencias de sus pesares, Nápoles, Carlo Porsile.

Junius, H. [1565], Emblemata, Antuerpiae, ex officina Christophori Plantini.

La Perriere, G. de [1539], Le Theatre des bons engins, Paris, Denys Ianot.

Lamarca Ruiz De Eguílaz, R. [1997], «Tradición clásica y exégesis medieval en la literatura de emblemas hispana de temática profana. La iconografia de la sirena», Boletín de Arte, $18,63-89$.

López, D. [1615], Declaración magistral sobre las emblemas de Andrés Alciato, Nájera, Juan de Mongastón.

Luis De León [1950], La perfecta casada, en A. Mari (Ed.), Madrid, Aguilar.

LuJÁn, N. [1988], La vida cotidiana en el Siglo de Oro español, Barcelona, Planeta.

LujÁn, P. de [1571]. Colloquios matrimoniales, Zaragoza, viuda de Bartolomé de Nágera.

Maravall, J. A. [1984], "La literatura de emblemas como técnica de acción sociocultural en el Barroco", Estudios de Historia del Pensamiento Español, Serie Tercera, Madrid, Ed. Cultura Hispánica.

Martínez Cabezón, E. [2011], «Medea emblemática: la femina furens en los libros de emblemas españoles", en R. ZAFra Molina y J. J. AzAnza LóPEz, Emblemática trascendente: hermenéutica de la imagen, iconología del texto, Pamplona, Universidad de Navarra / SEE, 469-484.

Martínez Pereira, A. [2006], «La representación del amor en la emblemática española de los siglos XVI y XVII", Península. Revista de estudios ibéricos, 3, 101-138. 
Mínguez Cornelles, V. [2010] «Matrimonio y emblemática: el rito de la dextrarum iunctio y la representación de los enlaces nupciales en la Casa de Austria», en I. Arellano y A. Martínez Pereira (eds.), Emblemática y religión en la Península Ibérica (Siglo de Oro), Madrid / Frankfurt am Main, Iberoamericana / Universidad de Navarra / Vervuert.

Nielfa Cristóbal, G. (coord.) [1991]. «Historia de las mujeres en España», en B. S. Anderson y J. P. Zinsser (coords.), Historia de las mujeres. Una historia propia, Barcelona, Crítica, vol. II, 581-651.

Pausanias [1994], Descripción de Grecia, lib. III-VI, int., trad. y notas de M. C. Herrero Ingelmo, Madrid, Gredos.

Plinio El Viejo [2003], Historia natural, vols. VII-IX, int., trad. y notas de A. Ma Moure Casas, Madrid, Gredos.

Plutarco [1986], Obras morales y de costumbres (Moralia), vol. 11, int., trad. y notas de C. MoRales Otal y J. García López, Madrid, Gredos.

Plutarco [1987], Obras morales y de costumbres (Moralia), int., trad. y notas de M. García VaLDÉs, Barcelona, Akal.

Reusner, N. [1581], Emblemata, Francoforti, Ieremiae Reusneri Leorini.

Reusner, N. [1587], Aureolorum Emblematum, Argentorati, Bernardum Iobinum.

RIPA, C. [1625], Della novissima Iconologia, Padova, Pietro Paolo Tozzi.

RIPA, C. [1987], Iconologia, Siena, Herederos de Matteo Fiorini, 1613; trad. del italiano DE J. BarJa Y Y. BARJa, Madrid, Akal (2 vols.).

Rodríguez De La Flor, F. [2001], «Eros barroco. Placer, matrimonio y censura en el ordenamiento contrarreformista», en R. САMACHO y A. Miró (eds.), Iconografía y creación artística. Estudios sobre la identidad femenina desde las relaciones de poder, Málaga, Centro de Ediciones de la Diputación de Málaga, 107-160.

Rodríguez Moya, I. [201 1], «Iconografía de la ceremonia nupcial y el matrimonio en la cultura simbólica europea», en R. Zafra Molina y J. J. AzAnza LóPez, Emblemática trascendente: hermenéutica de la imagen, iconología del texto, Pamplona, Universidad de Navarra / SEE, 731-748.

Rodríguez Moya, I. y Mínguez Cornelles, V. [2013], Himeneo en la corte. Poder, representación y ceremonial nupcial en el arte y la cultura simbólica, Madrid, CSIC.

Rodríguez SÁnchez, Á. [1996], La familia en la Edad Moderna, col. Cuadernos de Historia 20. Madrid, Arco Libros.

Russel, D. [2005], "Wives and Widows: the Emblematics of Marriage and Mourning in France at the End of the Renaissance», en A. SAunders y P. DAvidson (eds.), Visual Words and Verbal Pictures. Essays in Honour of Michael Bath, Glasgow, Glasgow Emblem Studies, $141-160$.

Sebastián LóPez, S. (Ed.) [1985], Alciato: Emblemas, Madrid, Akal.

SEnÉs, G. [2006], "Atributos simbólicos de las virtudes femeninas en los emblemas de Alciato y en la tradición de los Hieroglyphica», en I. Calero y V. Alfaro (coords.), Las hijas de Eva: historia, tradición y simbología, Málaga, Centro de Ediciones de la Diputación de Málaga, 163-182.

Simeoni, G. [1574], Le imprese heroiche et morali (editada como continuación del Dialogo dell imprese militari et amorose, Lyon, Guglielmo Rovillo, 1574, de Paolo Giovio).

Sото, H. de [1599], Emblemas moralizadas, Madrid, herederos de Juan Íñiguez de Lequerica (Edición facsímil e introducción de C. BRAVo-VIllasante, Madrid, Fundación Universitaria Española, 1983). 
Tervarent, G. de [2002], Atributos y símbolos en el arte profano. Diccionario de un lenguaje perdido, Barcelona, Ediciones del Serbal.

Testón NúÑEz, I. [1985], Amor, sexo y matrimonio en Extremadura, Badajoz, Universitas.

VAleriano Bolzano, P. [1567], Hieroglyphica sive de sacris aegyptiorum, aliarumque gentium literis commentarii, Basilea.

Van Veen, O. [1701], Theatro moral de la vida humana, en cien emblemas, Amberes, Henrico y Cornelio Verdussen.

Verheyen, E. (ed.), William S. Heckscher, Art and Literature. Studies in Relationship, col. Saecula Espiritualia, Baden-Baden, Verlag Valentin Koerner, 1994, 97-109.

VIGIL, M. [1994], La vida de las mujeres en los siglos XVI y XVII, Madrid, Siglo XXI.

VILLAVA, F. de [1613], Empresas espirituales y morales, Baeça, Fernando Díaz de Montoya (Ed. crítica de M. Pérez Lozano, La Emblemática en Andalucía. Símbolos e imágenes en las Empresas de Villava, Córdoba, Universidad de Córdoba/Grupo ARCA, 1997).

VIVEs, J. L. [1528], Libro llamado Instrucion dela muger christiana, Valencia, Jorge Costilla. VIVES, J. L. [1947], Obras completas, ed. y trad. de L. Riber, Madrid, Aguilar (2 vols.).

Whitney, G. [1586], A Choice of Emblemes, and Other Devises, Leyden, Francis Raphelengius.

Zárraga, F. de [1684], Séneca, juez de sí mismo, impugnado, defendido, y ilustrado, Burgos, Juan de Viar. 